S 521 M69

Copy 1 
बर्ब

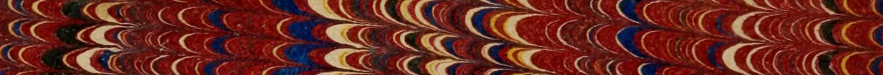

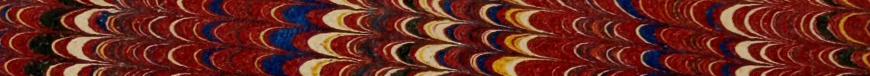

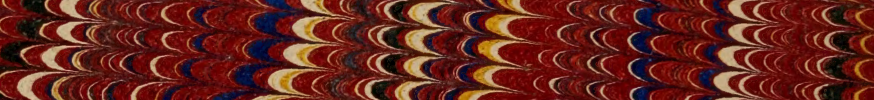
$\sec (0$

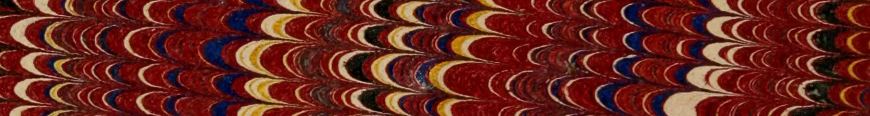

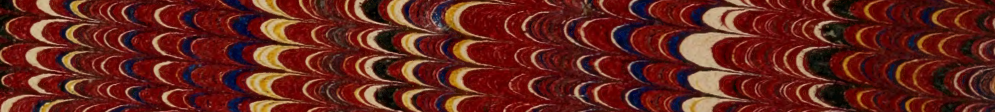

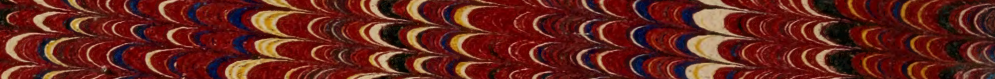

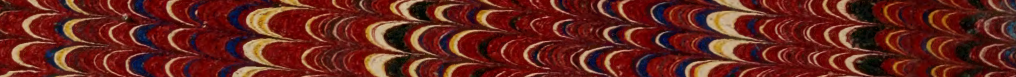

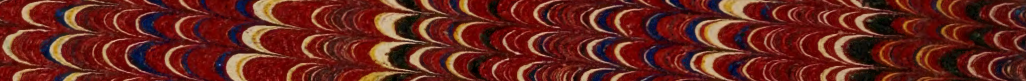

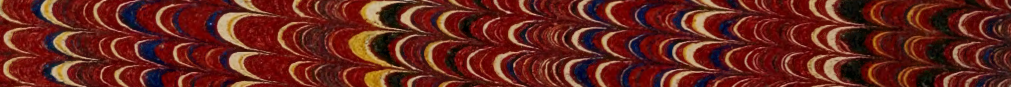

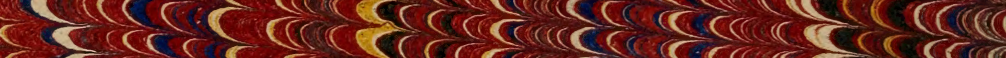

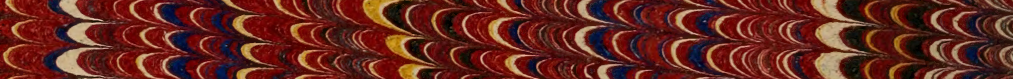

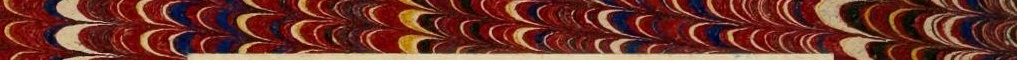

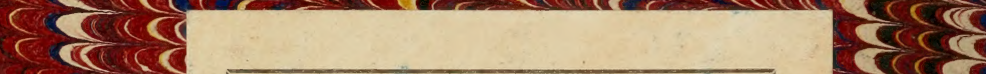

बर्ष

से कर

Cतs

तes

cera

deris

Cerce

cere

$\sec (c)$

लेखल

serer

Dithraty of Congress.

relape. S52

Splielf: M 69

Copyingt $\longrightarrow$ Pa.

UNITED STATES OF AMERICA.

cerces

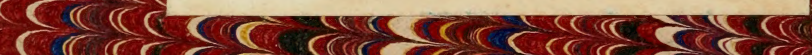

c)

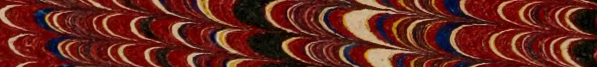

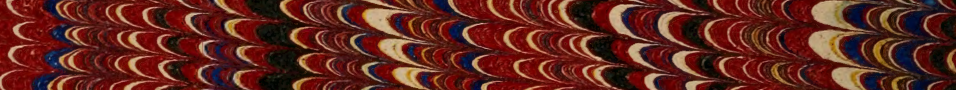

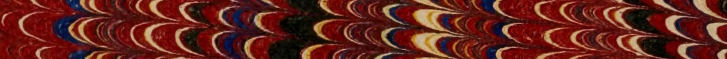

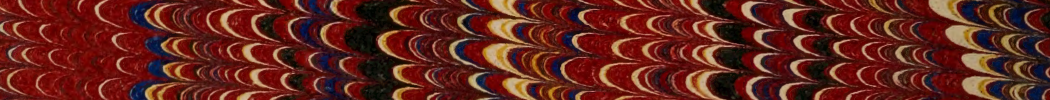

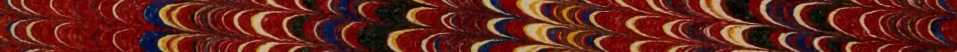

तC

ब(e

दे

खे

cर

बricence

eres

बिलिखि

ces

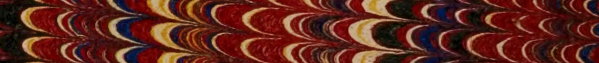

$4 \sqrt{6}$

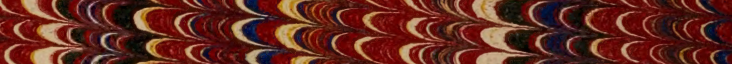

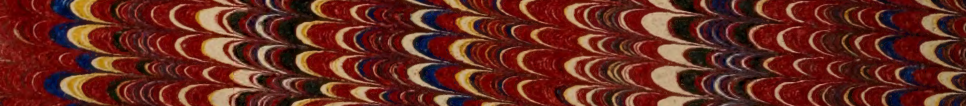

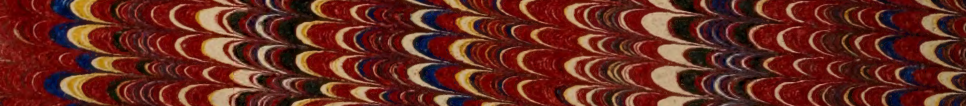

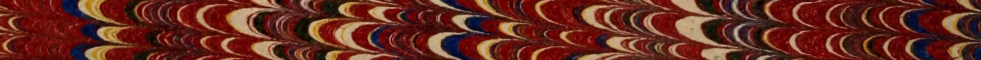

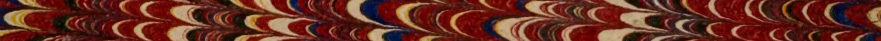

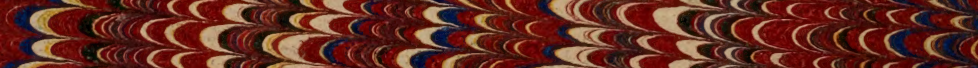




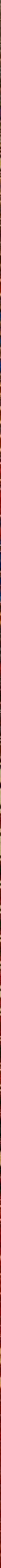









\section{FIVE THOUSAND A YEAR; $7664, a$ \\ AND}

\section{HOW I MADE IT}

IN

FIVE YEARS' TIME, STARTING WITHOUT CAPITAL.

$\mathbf{B Y}$

EDWARD MITCHELL.
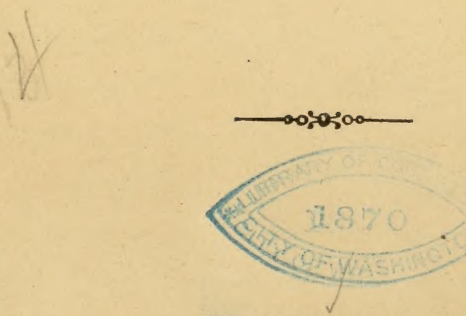

\section{LORING, Publisher,}

319 W A ShINGTON STRET, BOS TON. 


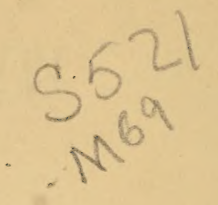

Entered according to Act of Congress, in the year $18 \% 0$, by

A. K. LOR I N G,

In the Clerk's Office of the District Court for the District of Massachusetts. 


\title{
FIVE THOUSAND A YEAR;
}

\author{
AXD \\ HOW I MADE IT.

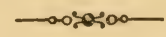

\section{CHAPTER I.}

EARLY HISTORY - LIFE IN NEW YORK-WHAT IT LED TO.

IN 1856, misfortune overtook my father in his mercantile pursuits, and avaricious creditors eagerly gathered up the very last item he had accumulated for years.

Consequently I was forced to give up the cherished idea of a college education, and go forth to grapple with the stern realities of life. I had been exceedingly fond of my books, and learned readily; this was all my stock in store, with which to go forth to make my way in the world.

Born and bred in a western country town, I had large ideas of a city, and was convinced it was the great field into which one must only enter to come out well supplied with earthly goods.

Led by this vague guiding-star I went forth, believing the great city of New York should be the Mecca towards which I must journey, and there find my fortune. I 
arrived in New York, and found myself a stranger in a - strange land. Without a trade, I had nothing to recommend me; no friends to intercede for me. Without any particular knowledge of anything whatsoever, and without any business experience, I was forced to withdraw as often as I applied. A cold and heartless world it appeared to me. Day after day I searched up and down through the great city, to find night overtaking me, with nothing accomplished, without lope, and daily becoming more and more discouraged, until I found the little means given me by a kind mother, with her blessing, dwindling down. Poverty began to stare me in the face, and that matters would come to a crisis soon was very evident. Thus driven to the last extremity, I hired out as a boy to a broker, upon the magnanimous sum of one dollar and twenty-five cents a week.

Of course this did not pay very well ; but in six weeks' time I had made several acquaintances, and I found another situation, which paid me four dollars a week.

For some two years I roamed from one position to another, watching my opportunities to secure each year better pay and prospects, until at last I was rewarded by a position as assistant book-keeper in a wholesale house, in which I soon became one of the fixtures of the institution.

After three years of devoted and strict attention to business, I was permitted to draw eight hundred dollars a 
year for my services. By purchasing all my clothing at wholesale, I succeeded in making all my points meet.

In this situation my hours were from eight to five, and my evenings were devoted to reading and improving my mind.

This was a pleasant and cherished pastime, and my taste ran more to history, biography, and the sciences, than to novel-reading.

During this time I felt sorely the bondage under which I was forced to live, for my necessary support. I longed to be a free man, to be my own master; but in vain. Every avenue into which I might wish to enter, every opportunity whereby I might turn the course of money into my pocket, seemed blockaded with the simple fact that I possessed no capital. The more I butted against these stern facts, the more vexed I became, and the more determined I was that I should fight my way into some business, for my own account. But alas! it was all in vain. I had no moneyed friends to help me, no rich relation to die and leave an estate, however inconsiderable.

I had become fully convinced that no chance would be left for me as partner in the firm, however useful I might become, as my employers had large families, and sons just ready to come upon the scene of action. Other fields must be found, and the sooner a foundation was laid the better. By chance, I read one day an article on smallfruit culture, which interested me, though some of the 
statements appeared rather exaggerated. Out of mere curiosity I visited the markets, and was surprised at the immense amounts and profits of the business. I said at once, this is the work for me; why cannot I raise fruit, and berries, and vegetables to sell as well as anyone? Upon a more diligent investigation I became more throughly convinced, and was not long in deciding that some such occupation would be my best forte. I then resolved to spend my winter, reading upon agriculture and small fruits, to save every penny to the uttermost, and in the spring go into the suburbs, hire a small piece of ground, and spend my leisure hours in cultivating it as an experiment.

The more I studied the more I became interested, and confident of success. In the mean time I was searching diligently for information from practical truckers and fruitgrowers, and visited many of those noted growers whose names are familiar to the agricultural press. I found them very clever, and willing to impart information, which was in striking contrast with the all-grasping and avaricious men of the city. 


\section{CHAPTER II.}

SPRING WORK AND PLANS-SEARCH FOR LAND-SELECTION OF CROPS - EXPENSE OF STARTING BUSINESS - TRANSPLANTING FREAK OF JACK FROST - MY WORK, AND HOW IT WAS MANAGED.

Having prepared to enter upon a campaign more active than any of its predecessors, and a winter's reading and study having prepared me as far as a theoretical knowledge could avail me, I was almost a new man in all agricultural matters. Such had been the increase in my general information, and the great inspiration to activity that it had given me, that I felt confident I could proceed without trouble, little realizing what in fact was before me.

Many told me it was but a vein of enthusiasm, which would soon die out. A portion of it I admit was; but it served its purpose in arousing my ambition, and in spurring me on to the practical performance of much to my welfare, although I found my stock of knowledge was small compared with what I had yet to learn. Early spring came upon me before I realized the winter half gone, so deeply had I been interested in my studies.

By putting in practice the plans I had made the pre- 
vious fall, I had accumulated in the savings-bank the small sum of seventy dollars, - by laying aside ten dollars every month, no matter what were my necessities for using it otherwise. This was all I had in hand with which to commence operations.

How to invest this amount to the best advantage was now the great problem I had to solve. In whatever I undertook I had determined it should be done without the necessity of neglecting my other duties appertaining to my business in New York, for the first year at least; for I could illy affurd to throw up a sure and steady income for any imbrobability of suzcess. To accomplish this it would be necessary for me to establish my basis of operations somewhere within easy access of New York. To think of buying with my small capital was entirely out of the question, and my only alternative was to rent a small piece of ground adapted to my requirements.

I had acquired many useful hints from truckers, and also noticed that the largest number of them came principally from different portions of Long Island, and not very far distant either.

I searched and advertised without any success. I tried another expedient, of taking short rambles into the country suburbs near the city, and thereby was better informed of the general surroundings of the city than ever before, witnessing many things and learning many facts which greatly surprised me. It is possible for people to live in 
the city a lifetime, and know nothing of their surroundings. So much rock, and the great distance to the upper part of New York, or Manhattan Island, attended with the great inconvenience in travelling to and fro, was a great barrier to locating in that vicinity; while to New Jersey soil I was quite averse, although the means of transit were much more frequent and desirable than at any other place.

There was no other point apparently more convenient, or better adapted to my wants, which remained, than the Brooklyn or Long Island Shore. But even here I found trials and tribulations, though of a different nature. This city being spread over more ground, though not as thickly built up, had the same deficiency in means of transit, and the distance across the city to its suburbs was nearly as great. The soil in the suburbs was light and loamy, and quite free from stones, and to my untutored mind had every appearance of what I most needed.

The scarcity of houses left many lots in open ground, which were held principally by capitalists as a speculation, waiting for time and increase of inhabitants to raise the value of their lands. I picked out a nice plot of several lots adjoining, which I judged to be about half an acre, and made diligent search for the owner therenf, whom I found to be not easily persuaded, not knowing when he should sell; but finally he agreed to a lease for one year for one hundred dollars. He assured me I would not suc- 
ceed; if from no other cause, its proximity would lead some evil-minded persons to commit serious depredations.

My lease was dated from the first of April, and the first two weeks were spent in sundry preparations, among which was the securing of a boarding-place near at hand and convenient to the scene of my proposed labors. My own common sense told me that my ground must be first manured, then ploughed and harrowed; but what was most essential for my soil I could not divine, and upon applying to my books for information, I could come to no more cefinite conclusion. To purchase manure in such quantity as I should need, and the cost of delivery, would draw upon my treasury an unwarrantable amount. It occurred to me at this time that the sweepings from the streets of the city must contain a large amount of fertilizing power and mineral properties, while the expense would be very small. Upon application to the street commissioner, he readily consented to supply me with all I should want, delivered upon my plot for twenty-five cents a load.

Early rising was a habit I was forced to acquire; for by so doing much valuable time could be economized, and I proposed to devote every available moment to my new work. The first morning after I was ensconced in my new home I started out early, with a shovel in my hand, and employed myself vigorously in spreading my street sweepings thinly over the ground.

This work came rather hard at first, and left indelible 
impressions upon my hands, consequent upon my long exemption from physical labor. But on the whole I felt better for it, and a few mornings sufficed to see this work all completed. A neighbor had agreed with me to do the ploughing and harrowing - which I found performed in a neat and creditable manner, one night upon my return home - for the moderate sum of three dollars. My ground was now awaiting my disposition, and my plans and books were at once consulted, for my next move in detail. I had thought it best to devote my principal attention in my new experiment to the cultivation of cabbages and tomatoes, combining with them such other plants as would assimilate without harm, and with a show of success. The tomato (so says the book) is one of the most important of all garden products, and the facility with which it is managed places it readily under the control of the least experienced. But to produce early crops the seed must be put down in hot-beds, or forcing-pits, some ten or twelve weeks before the plants are fit to be placed in the ground. How encouraging! It was now the middle of April. In twelve weeks' time I could have plants fit for transplanting; that would be the middle of July, before which time I should have tomatoes for sale by rights. A second consideration was the expense of the hot-bed, and the probability of its success at so late a day. One of my principal objects was to secure early produce for the market, and this would not do at all. 
To recover this lost time I must secure from some gardener a quantity of plants sufficiently advanced to be ready for the open ground, which was accomplished by the expenditure of no little time and trouble.

An abundance of rank stock, with short, stubby roots, and otherwise of medium class, were found, but my selections were of those well advanced, with long and a plenty of fibrous roots. Perseverance insured my success, and I secured my tomato plants at an average cost of one dollar and twenty-five cents per hundred, and cabbage plants for seventy-five cents per hundred. I secured my cabbage plants at the same time, thus saving a second search for them. I found it necessary to exercise much precaution in planting; and that it was far preferable, in fact an essential object, to have a dark or rainy day in which to set them out, which would prevent them from being wilted by the hot sun before their roots had taken hold of or begun to work in their new soil. As this would be a loss of time which I could not admit of, and the nights being warm for the season, I labored by the light of the moon, covering each plant with a bit of paper to protect it during the coming day, and every morning for a fow days sprinkling them with water.

I set them out in rows three feet apart each way, and placed a small handful of stable manure around each hill, two loads of which I had previously provided, at an expense of two dollars per load, delivered upon my 
ground. The cabbages were likewise set out three fect apart each way, and treated in every respect the same $\mathrm{s}$ tomatoes.

They had come to me well prepared, set in small boxes of earth, containing from three to four dozen each, that they might keep well for some time.

In a week's time I had accomplished the whole work with my own hands.

Two April showers were timely given, which helped to sustain the life of the plants after transplanting, and I saw no indications of losing any until about a weck after they were all out, when a sudden change in the weather one night brought on a severe frost.

Upon going out in the morning, and finding Jack Frost revelling in his sports upon my tomatoes, I felt quite unpleasant towards him, for I was certain my work would have to be done all over again; but happily he succeeded in laying waste only about one hundred of them, which I speedily replaced. My two hours' work every morning brought me great enjoyment after the first few days' fatigue had worn off.

The interest in my work had brought on the habit of early rising more easily than I had anticipated, and upon the whole my new pursuits appeared to better capacitate me for the more proper performance of my daily duties in my business, while the result for the better in my health was quite apparent from the first. My whole soul was 
now thoroughly aroused, and appeared to pour itself into this one channel with such unwonted power that my business in the city began to lack the interest which $I$ had formerly found in it. I might say with safety that it was somewhat neglected. Working for hire in behalf of others had lost its charm, and an ambition for selfish interests had quite superseded it. 


\section{CHAPTER III.}

ECONOMIZING ROOM - AUXILIART CROPS - A HALF ACRE OF TRUCK

- Weeds versus crops - BatTle WON - STUdY OF NATUREPREPARATIONS FOR MARKETING - PRACTICE OF TRUCKERS PROFITS OF MIDDLE MEN - TO SAVE IS TO EARN.

Mr half acre was at this time covered equally with tomatoes and cabbages, yet much room was left which might be economized by growing some crop or crops which could be gathered at an earlier day, and which would not materially interfere with what I had already out.

My books now came into requisition, and I studied the nature and characteristics of various articles, which had any probability of meeting my wants. After much contemplation I decided upon planting lettuce and radishes.

There is, perhaps, no plant of the garden we could so ill afford to dispense with as lettuce. Few gardens of all classes are without it, and its freedom from insects and disease makes it one of the most easily-to-be-managed vegetables in the hands of any one. The plants intended to mature for an early market will require treatment similar to tomatoes and cabbages, and to effect that object they are set out in hot-houses as early as February, that they may 
be in a condition to transplant to the open ground so soon as the frost has, left it in the spring.

Lettuce generally matures its crop in about half the time it takes for tomatoes, and about one quarter as long as is required by cabbages, and therefore is all cut off before it can in any way interfere with them.

I had no other course than the one pursued previously in getting my other plants, that of purchasing lettuce plants from professional gardeners, which was an additional expense. By the last week in April they were all set out between my rows of tomatoes each way, and all looked very promising.

My plot of ground consisted of ten city lots, twenty-five feet wide and one hundred feet deep.

They were so situated that five fronted on one street, and the remaining five upon the next street below. The whole plot was one hundred and twenty-five feet wide and two hundred feet long.

One half of this was set out with tomatoes, which gave me thirty-three rows, averaging forty-one tomato plants each, or a total of one thousand three hundred and fifty-three.

In each of these rows I had placed a row of lettuce, eighteen inches apart, and eighteen inches from each tomato plant. This gave me thirty-two rows of lettuce of eighty-two in a row. In each row of tomatoes between each hill, I also placed a lettuce plant, which gave me thirtythree rows of forty each, or a total of three thousand nine 
hundred and forty-four lettuce plants, which, if they all lived and matured well, would make quite a handsome little crop. I have endeavored to show how systematically and economically I had disposed of this first half of my garden plot, and as a first attempt I thought it well conceived and executed, and therefore proceeded to make a similar disposition of my second half. This was not so readily accomplished. Radishes, like lettuce, prefer a very light soil as well as rich, to produce a fair crop; while my books said they were usually sown broadcast and harrowed in.

How to do this, with my cabbages already set out, was beyond my ability to conceive; but after much reflection I originated an idea in my head, as I thought, but which afterwards proved but a common practice among gardeners of long standing.

My idea was to make a little furrow with my hoc-handle between the rows of my cabbages, and then cover them by lightly shoving the back of the hoe over the row. This was a much longer and more tedious job than I had anticipated, and perhaps the most unprofitable of any part of my experiment. Having a rather treacherous memory, I was induced to provide myself a small pass-book, which I could carry in my pocket, and had been careful to note down my proceedings each day, and marked therein the different phases of my plants and work, as it was observed from day to day. A few pages were also set apart 
for suggestions which would occur to me, and needing further study or a practical demonstration. I had therefore not only a correct data of all transpiring around me, but ample scope for meditation.

A book of this kind adds much to any one's knowledge, and helps to form a systematic way of doing all things. System is the great corner-stone of a man's existence.

By this means I was sanctioned and aided in pursuing my experiment in detail in many practical directions. The reader may have cause to laugh at these things; but he must remember I was actually ignorant, and trying hard to learn, and in my attempt ofttimes I arrived at well-known and practical truths by the most circuitous routes. By so doing I think a deeper impression was made upon my memory than had I been told it by one who knew. I had noticed that a few hills of tomatoes, around which I had loosened the soil very frequently, and more often than the rest, were growing up more rapidly.

Being unable to find any other reason, I concluded that frequent stirring of the soil was more conducive to the rapid growth and more complete development of the plant. Weeds will grow where nothing else will, and just where you do not wish them. They were very provoking, and it soon became a matter of necessity rather than of theory, that I should raise the hoe with skill, and attack these little enemies all over my plantation, lest the devastation of this little army should lay waste my fields 
and empty my granaries. The weather was quite propitious, and every diay bespoke the near approach of summer in earnest. Weeds grew in spite of all I could do, and for some time seemed to threaten the total annihilation of all my plants.

It was the hardest battle I had ever fought, but victory was my final reward.

After I had subdued these obnoxious intruders, I could almost see my plants grow, and I continued to hoe them over and over again, keeping the soil almost constantly stirred. April showers appeared to be more abundant this season than I had ever noticed them, and kept with us until late in May, and their beneficent influence was felt alike by weeds and plants. With every fresh shower it would appear as if a new crop of weeds had been sown, which needed just those few hours of warm sunshine to bring them out. The old saying that toads were brought down by showers appeared to be changed, and weeds substituted in their place. A constant dropping will wear away a stone, and encouraged by this maxim, a constant dropping of the hoe upon them kept them under pretty good subjection.

My out-door exercise had produced a wonderful change in me, and among other things the most notable was the increase of my appetite. A remark to this effect by the landlady, at this time, touched me rather sensitively, and I began to fear lest she might advance the price of my 
board, and here would be a dilemma; for a financial pressure of this character, under my present circumstances, would have been a blow under which I would be unable to exist. I had assured her I was a delicate eater, and had done so conscientiously; but when a review of the immense amount of the substantials which I passed out of sight was taken into consideration, I was not surprised that she should doubt my veracity. I endeavored to assure her all would be right, and set forth very temptingly how I would before long be able to supply her table with some choice regetables.

I was confident that it was nothing else than my out-door exercise which was the innocent cause of my great appetite. Dyspepsia no longer interfered with digestion.

I was no longer the thin and slender man I had formerly beheld in the mirror, with a pale, ghostly complexion; but full and brown, heavier and happier than ever before.

I am digressing, however, at an improper point, from my story. My course had been entered upon and I must run the race, win or lose. As the season advanced, I watched with much pleasure the unfolding of each leaf and the maturing process of each plant, closely identifying the works of God, which were truly wonderful! It was with a rare delight I was seized, the day I discovered my first little green tomato, hanging so gracefully 
from its shaded bower, and I moved with a quick step and a light heart, full of encouragement.

It was a timely warning to me that the sowing and seed time was fairly in the past, and that the harvest would soon be here. A glance into the future harvest time, for it appeared as though my life was then confined within the seed time and harvest, pointed out plainly that there was work of a different nature at hand in the preparation for gathering my crops. I must be prepared for the marketing of my products, and have all things provided and ready, that there might be no delay when harvest time arrived.

This was my first experiment, - not just to see what I could raise, but to assure myself what income could be derived from it, and it was to receive a fair trial at my hands, either for profit or loss; and accordingly I looked with care into the various means practised of transporting produce to market, and how it was marketed.

It was customary for parties living at a distance, after gathering their produce, to pack it neatly and with care in some appropriate box, basket, or other article, as its requirements might demand, and ship it by railroad or boat to the city market, consigned to some good commission agent, who would sell and deduct a percentage - generally five per cent. - for his pay. I was so situated as to have no railroad or boat facilities, and, besides, I could ill afford to pay a commission merchant for selling it. 
The latter argument was given up, however, for I found it was a difficult matter to get one of these dealers to trouble themselves with such small consignments as it was represented that I should make. Another method adopted among near-by truckers was to load up their wagons, and start for the market early in the evening, riding all night just so as to arrive in market at the break of day; or if they lived very near, they would start in the early hours of the morning, gauging themselves according to the distance they were obliged to travel. This method I could in no wise adopt, for it would first necessitate the purchase of a horse and wagon, which was beyond my means; and then being deprived of the necessary amount of sleep, required for my duties during the day, would be incompatible with my interests.

Having abandoned both of these plans as totally impracticable in my case, I determined to spend a few evenings among the grocers of my acquaintance, to whom I stated clearly my case, and I found they readily assented to an arrangement which I thought would be highly satisfactory to all parties concerned. These city grocers are supposed to supply their customers with all kinds of vegetables, and in fact their trade depends upon the freshness and superiority of what they have; for in so large a city there is a large competition, and grocers are abundant, and people do not hesitate to go from one to another, they always having the cash in their hands. Of course, it is an 
object for every grocer to have the very best, to secure such customers.

Therefore I found the grocers not only willing to give me a better price, but they willingly agreed to send their own wagons the short distance required, to get a fresh article.

I say a better price, but it was really the price nearest that paid by the consumer, and being the profits of all the middle men put into my own pocket. If sent to the commission merchant, they are sold by him to the regular dealer, he in turn disposing of them to another dealer, or to the grocery-man.

Again, produce generally offered for sale of a morning by the grocery-man has already been at least twenty-four hours plucked from its bed, this time being required in its transportation and passage through the dealer's hands.

In this arrangement I made, I was at no expense for baskets, in which to pack my produce; for having an abundant supply for other purposes they brought them out for me to fill. Having satisfactorily arranged all these preliminaries, I was now prepared to receive anything Dame Nature might choose to grant, and anxiously and closely watched the consummation of my experiment.

A tolerably good fence was upon the lots when I took possession, and I had devoted some odd moments from time to time in putting it in good repair, thus preventing the 
depredations of any unruly cow which might be disposed to gratify her appetite by the tempting display in $\mathrm{my}$ garden.

Fortunately my neighbors did not possess any little pigs or chickens, and no thieves were tempted to trespass upon my domain, although the latter was my greatest fear.

Within the limits of a great city there necessarily accumulate many people, of many minds, and that community which is free from evil-disposed persons, who seek to obtain dishonestly those things they have not the ambition to acquire honestly, would be one well worth visiting, for it is very rare. This was the burden of my fears, locating in the suburbs of so great a city. But if there were any such, they failed to give me a call, which I in nowise regretted. Long and protracted rain-storms were frequent, as well as drawbacks, this season; but for all of that, time sped on until the first harvest, and I could do no more than abide the result. 


\section{CHAPTER IV.}

FERTILTERS - FIRST SALE - AN EARLY MARKET - RETURNS FOR produce-A Dollar saved is two dollars eArNed AUXILIARY CROPS - TOMATOES.

A this point I could not do otherwise than speak well of street-sweepings, although I did think the great amount of weeds I had to conquer was somehow attributable to the fertilizers I had used. I had no reason to complain however, for the result thus far had been all I could expect from any of the accustomed fertilizers. It may have been just the particular article needed to recuscitate the soil I had to cultivate, while in another instance it might be ontirely useless.

This result is equally as liable to occur with any of the ordinary fertilizers employed as well as this. I have often seen two fields side by side, with only a fence to separate them, and while the soil would be every way analogous, and treated precisely alike, the one would produce remarkably good crops, while its neighbor would produce crops exactly the opposite.

Much depends upon the requirements of the soil, which can be determined only by a series of crops raised from it 
upon successive trials. My land, not having been cultivater for several years, appeared to accept this donation very gratefully, and threw a great amount of power into the growing properties of the plants.

The middle of May was now at hand, and my lettuce was showing some very large heads. We had already had two or three messes for our table, and it was very fine and tender.

I was now watching the market very closely, and had seen but a very few heads exposed for sale. Towards the last of the month it became more abundant, and the ruling price was five cents per head, although grocery-men were selling it for twelve and fifteen cents.

One morning I started out with a bundle of sticks, and marked all the largest heads I could find, until I had made out five hundred.

On my way to the city I informed two of the grocerymen I could deliver thern, at an early hour, two hundred and fifty heads each, at ten cents, upon the following morning. Their wagons were on hand at a bright and early hour, and it was the work of a few moments to gather the heads I had marked out the previous morning. Such hearls of lettuce I had never seen, for some of them would entirely conceal a good sizeed dining-plate. They were beauties for me to behold.

I continued to supply my landlarly with all she desired for her table, and it would be unnecessary to repeat her ex- 
pressions of gratitude, nor what pleasure I had in partaking of it, especially as it was grown by my own hands.

On my way to the eity I stopped at the grocers, and found them highly pleased, and received from them the first returns for my labor, just fifty dollars; and could I really believe my eyes? I was not quite sure it was more than a dream, and a second and a third investigation, as I pursued my course to my business, only tended to assure me that I had just fifty dollars, and that it was really in my pocket, and the result of my own labor.

I had brought every exertion, and all the available knowledge I possessed, into practice, that I might hasten my crops into an early market; and it was only a fact made more evident, that could I have had more I should have gained a greater profit; but I had them not, and nearly a week rolled by before I had lettuce again for market, and then the price had fallen. The market was becoming rapidly stocked, and the best heads only brought three cents. It was evident to me that the balance would be ready for market at about the same time, and I adopted the course of selecting and marking out those most matured one morning, and delivering them upon the following morning, thus marketing every other day until all I had was disposed of.

Previously I had sold five hundred heads at seven cents, netting me just thirty-five dollars. Subsequent sales ran as follows: five hundred heads at five cents, four hundred 
at four cents, one hundred at two cents, four hundred at one and one half cents, and a balance of nine hundred heads at one dollar per hundred, - making my total receipts from lettuce one hundred and fifty-three dollirs. I had some left, which were unmarketable, besides what I had used myself, given away, and otherwise disposed of. I had picked out thirty heads also, intending them to run to seed. I was more advantageously situated than many, and readily accessible to the market from my business, and could easily watch the fluctuations of the market.

My receipts were trivial in amount when compared with larger producers; but I could afford to take considerable more trouble, which on a larger scale I would avoid. A dollar saved was two earned, and if I could save just that dollar by a little extra trouble it was my interest to do so under those circumstances. I was also taught, by those first experiences, that it was the early bird which caught the worm. Competition is not altogether a drawback, but more the support of trade; for without it we cannot project or carry out the great and solid issues of the day, and yet we are vainly striving to clear ourselves of it, without success.

There is no business into which we may enter but what has its competition, and it is equally true with the cultivator of the soil; he strives to overreach his neighbors, and if he succeeds in reaching an early market, he has not long to reap its benefits, for his neighbors and competitors in the race are close upon his heels, and as the market be- 
comes more abundantly supplied, the price must fall to accommolate it. If fortune favors one with suitable weather, combined with early planting and good care, he may reap a rich harvest in an early market; but tide and winds are not always fair, and he is often prevented by these unforesecn circumstances, which are heyond his control, from reaching a market until it has become abundantly supplied; hence he gets small prices, and as the result becomes disheartened and discouraged, and thereupon affirms that farming don't pay.

Such people are of just that class who readily place the blame of their ill-success upon anything else but their own management, and are sure to ery down all things, persons, or books, which are striving to educate the people in their business, by holding forth their success as a guide and example.

I met an old farmer a ferw days sinee, whom I knew had always been opposed to book-farming, as he called it; and so strong was his antipathy that he positively refused to look at any book on farming, and never would subscribe to an agricultural paper.

In the course of conversation he took occasion to reiterate his opinions to me, when $I$ asked him if during his life he had made farming pay. Most certainly he had. "Well," said I, "would you advise a person to commence as you did, and work up; or would you rather tell him, and save him some of the misfortune you have experienced?" 
Now the old man was very kind-hearted and social, and would never withhold any information asked of him. "Oh," said he, "I should not want any one to pass through all I have. I could teil any young man so he could get along firstrate, and save himself a deal of trouble which I got into just because I knew no better, and had no one to advise me."

"Well, then," I said, "if you were to write down on paper a history of all you have done, and troubles you have encountered and overcome, and it was printed and put into a book, would you consider it as good a guide as if spoken by your own lips?"

"Most assuredly I would," he replied.

"Well, then," I responded, "I have a number of books, written by men situated just like yourself, who have passed through similar breakers, and come out safe and successful; and yet you laugh at me because I read them, and make their experiences my study, and call it bookfarming. Surely you are very inconsistent, and would fecl deeply injured were I to treat a book you might write, as you do others' books."

The old man was somewhat puzzled at first, and went away promising to think better of books in future. A short time afterwards I got his subscription for an agricultural paper, and he is very fond of looking over the books in my library quite frequently.

IHow well I succeeded, and the effects of strong competition upon my sales, is clearly shown in the quotations of 
prices given above, all of which occurred in the bricf space of two weeks. As fast as the lettuce was removed I went over the ground with a hoe, spending two hours each morning, at night an hour, - which might seem to many very small, but in the aggregate amounted to considerable, besiles keeping my mind fully occupied, and my ground thoroughly tilled. My radishes appeared to be rather a drawback, and I was not very much predisposed in their favor.

When they became marketable I accepted an offer of one dollar and a half for them by the hundred, and let them go. They turned out rather small, but good as far as they went. The turnip-root radish was the kind sown, principally, because I had heard them highly extolled, and as the most desirable for an early market; but from my cxperience I could not indorse them. The price received did not satisfactorily remunerate me, - the whole crop, when gathered, amounting to only thirty-two hundred, and bringing me but forty-eight dollars. Of my auxiliary crops it will be seen the radishes brought me but onethird the amount my lettuce returned.

From the first to the middle of June, my tomatoes engaged the best part of my time, and the amount of attention they demanded began to require more time than I had to devote to them. This strong indication of the necessity of more labor urged upon me the acquisition of some outside help. 
I supplied myself with a quantity of stakes about five feet in length, pointed at one end, and drove one by each vine, to which I tied up the vines loosely, which served to keep them clear from the ground, and give the sun and air more easy access. All that I succeeded in treating in this manner I was not disappointed in seeing mature more rapidly than those which for lack of time I had left to follow their own inclinations upon the ground. Thus arranged, I could easily walk through and work among them. My cost for stakes and twine was twelve dollars and fifty cents.

About the middle of June I saw indications of a few tomatoes turning, and in two weeks more I looked for my first marketing. In looking about, I found I could dispose of them to the grocery-men, as I had the lettuce, only in this case I must furnish my own baskets. For this purpose I purchased what is commonly known as the peck or tomato basket, at twenty cents each. I considered two hundred quite a supply, and all I should need for the season.

The weather continued warm and fair, and the weeds grew vigorously, and the cabbages were suffering for another hoeing; tomatoes would soon be ready to gather, and work lay on every hand. I saw no remedy for the deplorable condition into which I was fast merging, except by hiring a laborer. I secured a faithful old colored man, who came well recommended as a gardener, for two dollars per day. 
The use of a horse and wagon was also arranged for, if needed, and by these additional helps all was restored to what I believed a necessary and proper condition. 


\section{CHAPTER V.}

MARKETING TOMATOES - CONDITION AND SUPPLY OF THE MATKETMARKETING CABBAGES - SALE OF TURNIPS - SUMMARY OF THE XEAR'S EXPERIENCE.

Simpments of tomatoes from Bermuda were received in the New York market this year as early as the fifteenth of May, bringing two dollars and fifty cents per crate of five quarts, or, in other words, fifty cents per quart. By the first of June the price had fallen to one dollar and fifty cents per crate, and June nineteenth they were selling for seventy-five cents per crate. This fall in price was produced by the arrival of the first from Norfulk. The distance which the first had to be transported necessarily detracted from their value when compared with the more fresh article received from Norfolk.

Norfolk tomatoes, therefore, brought a higher price, being more desirable, and sold for one dollar and fifty to one dollar and twenty-five cents per crate. These early shipments brought good prices, and the shippers participated in large profits; but a home article had a good market awaiting it, and the first lots from New Jersey brought twelve dollars and eighty cents per bushel, or forty cents 
per quart. The Southern facilities for raising produce for an early market are superior to ours, and for a short time they reap a liberal profit; but the distance they have to travel, and the rough handling they receive, neccssarily decrease their value when put in competition with our home fruit; yet these shipments have their effect in bringing our home produce into market at a lower rate than it otherwise would without this competition.

I had been anxiously hoping for'my tomatoes to ripen; but the stormy weather had put off the harvest until the twenty-fifth of June. The first lot of tomatoes I gathered amounted to twenty peck-baskots, which I had carefully assorted, fecling that my reputation, as well as a good price to be obtained, would depend upon the superiority of the article I should market. I had determined upon sending my tomatoes to the general market, as I could not afford the time that would be required to sell and collect the bills, as I had with my previous crops of lettuce.

The first twenty baskets I had sent to market brought me one dollar sixty-one and a half cents per basket, - a total of thirty two dollars and twenty-five cents after deducting the agent's commission of five dollars and seventy cents and paying freight.

It was some days after this before I could gather another shipment, and in the mean time I received a note from my agent, - to whom I had previously stated I was a new be- 
ginner, and asked as a special favor, that he would do the very best for me, - congratulating me upon the fine appearance of my little consignment, and intimating that, at an early day, he should like to receive a similar consignment of one hundred baskets equally as good. I flattered myself that this was owing to the good care I had taken in assorting them. I permitted Henry, my hired help, to gather them, and in the evening I looked them all over, throwing out all imperfect or injured, and shipped one hundred baskets more, which brought me one dollar fourteen cents net. I noticed prices were on the decline, which, as the season advanced, I was sure would run very low. Every morning I took a good survey of my grounds, performing little jobs here and there, and laid out the work for Henry. Cabbages wcre maturing very rapidly, and were requiring attention, and withal I kept my laborer well occupied. I made but one more shipment to market, which was fifty baskets the first week in July, for which I received one dollar net. From this date the price fell very rapilly, until it was only nominal, and not worth the labor of picking. The second week in July, the grocers to whom I had sold lettuce called upon me, signifying their desire to be supplied with a good article of tomatoes.

I agreed to deliver them twenty baskets every other day as long as they should last upon my ground. The prico at the general market held at thirty-five to forty cents for about two weeks, and during that time I received from the 
grocers fifty cents per basket for one hundred and sixty baskets. About this time, I received from a party engaged in canning fruit an offer of twenty-five cents a bushel for the balance of my crop.

Owing to the pressure of my other business, and the attention required by my cabbages, besides the low figures the market had reached, I concluded it would be the better policy to accept his offer, especially as he was to pick them himself. When he gave me up the vines, he had picked sixty bushels, and paid me fifteen dollars as per agreement. I found my cabbages were very much annoyed with bugs, and the care and watching necessary to keep them off by hand were very tedious; as a remedy I suggested to Ilenry the idea of sprinkling some ashes over them each morning, for a few days, before the dew was off. To this he demurred very strongly, prophesying the utter destruction of my whole crop if so treated. I was confident I had seen my father do the same in his kitchen-garden in my carly years; but for what purpose I was too young to remember, but thought it must have been for some purpose of this kind.

I tried it upon a few heads first, and found it quite satisfictory, after which I gave an application of unleached ashes to the whole field, which quite thoroughly eradicated the bugs. It was nearly into the middle of July before I sent my first lot of cabbages to market, and realized, from two hundred and twenty heads, five cents each. As 
soon as my tomato vines were done bearing, I had them pulled up, and put one side in one pile and threw some dirt over them, hoping to have a little manure out of them.

I then made a brush-harrow, and scratched the ground over two or three times, and sowed turnip seed. In about four weeks from my first sale of cabbages I had disposed of the whole crop, receiving for four hundred head four cents, two and one half cents for three hundred heads, and two and one half cents for two lots of two hundred each. The remainder did not mature, while some I had used myself or given away. This crop was all off by the first of August, and I sowed this ground also to turnips.

My garden was now turned into one turnip-field, and, as I had little or no work to do, I had a few leisure hours for recreation and meditation. The first of September was soon at hand, and with its arrival I should make out my first.year since I had broken loose from my old routine, and given my ideas a larger and more practical scope.

September is, in fact, the beginning of the year to all cultivators of the soil, of all branches. Fall sowing, preparations for winter, housing of plants, and laying out of plans for a summer's work are then perfected.

Moreover, it is the best time to take observations and establish the prospects of the future upon a basis of the past experience. And, accordingly, was it not the most fitting time for me to consider the profit or loss of my first experiment as a gardener? So hastily conceived and so 
quickly executed, little time had been permitted me for sober reflection during the entire summer.

It was here, there, thus and so, and this the one needed and that the other demanded, as quick as ever it could be accomplished. Time and labor could only be given to meet all the wants, leaving no time unoccupied for meditation or observation.

Now I could review these scenes and study their results while they were fresh in my memory, and receive the lessons they taught.

But a year before, I was as ignorant of this business as a young child who has never seen the country. There are, however, very few children who have not been in the country, and have a general idea of what it is; but many a country child knows not of the city, and I trust many of them may never witness or indulge in its evils.

But in neither case are the stern realities of life more realized or understood than the duties of a mechanic are by the merchant. I might extend the comparison to the majority of men; for how vast and deep are the ways and responsibilities of every member of humanity! The city people all like to go to the country for pleasure, but few can ever arrive at the real merit of country life, save they have had a hand in the workings thereof. In my new avocation I was neither in the country nor the city, strictly spealing, but I had begun to taste some of its more stern realities. In experience and knowledge $\int$ had 
been transformed, and the unparalleled enthusiasm and egotistic confidence with which I had started out was now toned down to a proper level, while my determination of purpose increased as the other supports fell off. I found that, when I had thought I knew much, I knew but little, and that there was something to be learned every day I lived; and eventually I became an humble but eager inquirer after knowledge, which course I continue until this day.

My first year's experience was nothing like what I had expected; for my enthusiastic anticipations had led me to build large profits too quickly and upon too premature a foundation. But whatever were the disappointments or encouragements of that first year, or their causes, I can simply say, taking it all in all, it was a dear experience; and yet, dear as it was, if I were to-day without that experience, no amount of money could atone to me for it, and I think it is a chance if $I$ had been able to recount these scenes from the stand-point I now occupy.

It is well said that no person can carry on two occupations successfully at one time. To this fact I may attribute a partial cause for some of my drawbacks, which, in another light, I might not call poor success. The manner in which I had thus employed my spare time had been very conducive to my health and happiness. My mind was fully occupied as well as my hands, and I began to think I should bless the day when my last turnip was sold 
and all my affairs settled up. But when that day came, rest was not acceptable; for, without my labor and the complete occupation of my mind, I was lost, and longed again for active pursuit. Such is human nature, - never satisfied; never contented. No sooner are our wishes granted than we long for something else. Thus; when the summer's campaign was finally closed, and the first few days had worn away, I was again up and at it, as will be seen in succeeding chapters. My health was very much improved, as my weight would testify. My face was somewhat tanned, and I could not show any lily white and soft hands; but what was all that, compared with my grand result?

Ḣad I not accomplished my purpose? Had I not planned and executed my own work, and brought it to a successful issue? Is there no satisfaction in all these things? Try it! Make something by your own efforts, and see if you do not realize a degree of satisfaction beyond a precedent in your history. I was fond of my own work and achievements, as every. man naturally is; not given to boasting, neither, having accomplished one good work, so lost in the admiration of it as to forget to do another.

To work and do something for yoursclf, to achieve a name or an honor by your own ingenuity, and honorably, are the noble and advancing strides of a civilized people; and such a people are among those who boast of an American birth. 


\section{CHAPTER VI.}

FIGURES DO LIE- PLAN OF SEASON - MY TRIAL BALANCE. - MY PROFITS - SUMMARY OF BENEFITS NOT ESTIMATED BY DOLLARS AND CENTS.

I HAVE read a great many books, professing to give practical instruction, based upon facts and figures; but I find that figures can be made to lie as well as tell the truth. When I was a boy, they were wont to tell me figures could not lie; but now I am grown up, and see very quickly that figures are very often induced to lie, and are thus productive of very serious results. Many persons, innocent and unworthy of ill-treatment, have been robbed of their very last dollar, and made miserable for life; their ambition stunned, and their courage thwarted, and thus left to drag out an indescribable existence of poverty and woe, merely by the skilful manipulation of figures in the hands of avaricious and grasping persons whose conscience admits of no moral law. In most agricultural books we find more or less of their statements based upon figures, and some very poorly substantiated. I have yet to see that book in print which gives a clear and detailed account of every income and outgo. Until then I can 
hardly credit the author's facts, unless I give them a thorough examination; for some weak spot is almost sure to be found, or something omitted which, if shown up in a correct trial-balance, would completely disarrange their previous statements. In view of these facts, I would not undertake to give any of my figures, if I did not think I could satisfy the reader with a correct statement of every disbursement, as well as every source of income. In attempting, therefore, to give the reader a summary of my first year's experiment, I have appended a general statement of my accounts as they are to be found upon my books, - a set of which I always kept with the same precision and care as when it was my only occupation in the employ of other's. In so doing, I have not, from any delicacy, as many writers have, omitted my personal, or what may be termed my family, expenses. It may seem commonplace and inappropriate to this story; yet it is to my mind requisite and necessary, in order to show a true and just statement. My first half year was solely one of preparation; yet I date my year from the first of September, which is not only the true beginning of the cultivator's year, but was the time when I first started upon my plans, and without dollar of capital. My first half year I have entitled the preparatory season, and the latter the active season. By such a statement it may seem easy to conduct the business so long as the result comes out to a profit. At the commencement of the 
preparatory season I had nothing; at its close I had saved seventy dollars with which to commence the active season. My rent alone would more than cover this amount, but I arranged to pay that in monthly instalments, and my crops so came in as to relieve me from any temporary embarrassment. I ask a careful consideration of the following statements of my first year's work :-

FIRST YEAR. TRIAL-BALANCE.

Preparatory Season.

Salary, first six months, from business in New York, . . \$ \$100 00 Paid for board and washing, . . . . $\$ 19400$

" " transportation and incidentals, • . 2450

"6 " clothing (economized), . . . . 10000

"6 " agricultural books and papers, . . 1150

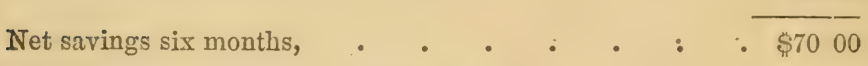
Active Season.

Balance brought down, . . : . . . . \$7000

Sales of lettuce, • • • . . . . . . 15300

"6 " radishes, . . . . . . . 4800

" " tomatoes, • • • . • • • . 29125

" " cabbages, . . . . . . . . 1450

" " c turnips, . . . . • . . . . 2500

Salary six months in New York, . . . . . . 40000

Inventory, tools, baskets, etc., • • • • • • 3950

Total receipts, . . . . . . . . . $\$$ 
Total Receipts,

$\$ 1,06825$

Paid for rent, . . . . . . . $\quad \$ 10000$

" " fertilizers, 100 loads @ 25c., . . 2500

" " garden tools, . . . . . 960

" " ploughing, . . . . . . 300

"s " tomato plants, . . . . . 1688

" " cabbage " . . . . . 1013

" " lettuce " . . . . . 1600

" " " radish and turnip seed, . . . . 300

" " 200 baskets, . . . . . . 4000

" " stakes and twine, . . . . . 1250

" " cartage, etc., . . . . . 1300

“ " labor, 9 weeks @ $\$ 12, . \quad$. . 10800

" " " personal expenses, six months, 32400

" " agricultural books and papers, • . 600

Balance to credit of bank first year, ! . . . . $\overline{38114}$ Deduct savings from salary, . . . . . . 14000 Net profit of half an acre, . . . . . . . $\$ 2414$

This to many would seem a very small amount in return for all the trouble I had experienced. It was not quite as satisfactory to me as I had wished; but, after reviewing it all, I thought it quite a respectable income, considering the source from which it emanated. Two hundred and forty-one dollars was a small amount of money; but to me, in those times when I was never able to save or make money beyond enough for my necessary expenses, it was a considerable item:

The experiment undertaken had proved of more value than any savings-bank. 
It is well for the clerk or the laboring man to lay aside a portion of his income every month against future wants, when he can faithfully adhere to it; but in nine cases out of ten it is never carried out, and even then of what value is the small amount he can thus accumulate towards inspiring him with ambition, and encouraging him in his business, or in giving him the buoyant pleasure of success upon his own responsibility? It appears to me more like the unfaithful steward, who went and hid what his lord gave him, lest he should not be able to return it after many days. The faithful steward put his money where it gave him good returns, and when his lord came paid it back with usury.

My savings of a year could not have possibly been more than one hundred and forty dollars, with a small interest of five per cent. What a savings-bank Mother Earth had been to me! I had deposited in her treasury one hundred and forty dollars, and received in interest the sum of two hundred and forty-one dollars, with the original.

Looking at it in another light, the percentage of my profits on the capital I had invested was very large in proportion to any other business. Very few classes of wholesale business or manufactories ever expect to make more than ten or twelve per cent. on their capital, while retail stores average from twenty to forty per cent. profit on their sales. In some instances as high as fifty and one hundred per cent. are made. My profit in percentage was nearly 
two hundred per cent. This was a process resembling in its results compound interest. It was turning over my money two or three times in a single season; and I ask you to show me a more complete or compact banking or commercial process within the control of one person than this.

Again, it is universally acknowledged that he who sets out to till the soil errs greatly in expecting a profitable return from the first year's labors. So strong is this belief in general that it has become a fact undisputed. This fact I had in mind, and my expectations were somewhat guided by it, although it was my intention to disprove it if possible. I failed, however, to substantiate it, and proved that it would admit of some variations. It depends entirely upon what you undertake, and how you manage it. I can see no more chance for latitude here than in any mercantile pursuit, and if ordinary good judgment, accompanied with determined execution, is exercised, there is no more, nor as much, chance for a failure. As an experiment it had produced strong evidence, beyond a doubt, that with more extended fields a larger and more profitable result could be attained. The great fault with farmers generally is to possess and wield large farms, and, consequently, they do not receive as much attention in proportion as those of a less number of acres. Every person should therefore be governed by the rule of cause and effect; and as the labor they have to devote to the complete tilling of one acre is 
to its profitable results, so will their labor, proportionately increased to the number of acres they have, be to a similar proportionate profit.

Again, the experience $I$ had acquired, if it were possible to estimate it in dollars and cents, would form a large item in my balance-sheets, and an equally large portion of stock on hand for a future season. Personally my health was so much improved that I could hardly believe myself to be the same person. There is nothing so beneficial to any one's health as free, open-air exercise and regular habits. To a robust and strong life dissipation and irregular indulgences are sadly detrimental.

Summing up all these results, what more encouragement could I have? What greater incentive to action? It is true I was not yet sufficiently able to enlarge to a very great extent my enterprise; but patience and perseverance I was confident would at no distant day crown my efforts with success, and I should be no longer a hired menial, subservient to the whims and fancies of moneyed men for my existence. 


\section{CHAPTER VII.}

A NEW YEAR - ANOTHER WORLD-ORIGIN OF THOUGHTS - FLORists - What I LEARNED - a GReENHOUSE - How IT WAS BUILT - COST OF GREenHoUSE.

A NEW year had dawned upon me, and a second year's work was in prospective. As to what it should be I had not fully determined.

Perseverance and application during my first year's trial were all that ensured to me what success I had received. As an experiment, it had practically diemonstrated the possibility of increased success, according to the ability I should devote to it. Unlike other business, I was not obliged to wait for a customer to drop in to buy of what I had to sell. I was not at all dependent upon the state of trade, nor did I have to hobnob with friends to influence their custom, slight as it might be. Mother Earth was all with whom I had to deal for my success.

The prospects of a winter before me at first appeared rather pleasant, as I felt a need of recreation from my duties for my overworked mind; but as the month of September began to wear wearily away, each day began to grow longer. My ambition relaxed. I did not feel that 
strong stimulation which moved me on, and gradually I began to long for something with which to occupy my mind. It is with great anticipation of pleasure that those few days of vacation from the close confinement and harrowing business cares, which the young clerk is granted once a year, are looked forward to. I used to look upon it as a boon of happiness; but alas! a few days of participation would suffice, and, notwithstanding all the pleasure and rest I derived, I found myself often wishing myself back again in my old routine. I cauld not bare to be idle, for to me it was the hardest work I could perform. The cause was plainly attributed to the lack of anything with which to occupy my mind, and such were my feelings, during the first weeks of September. Unable to endure this feeling, I began to look around for some means that I might avail myself of, for the more proper occupation of my thoughts and spare hours, which would help me on in the course I had begun. Not but that there was an abundance of ways with which to pass my time, in convivial pleasures, among my numerous friends, in so large a city; but a feeling possessed me to be no longer wasting my time in that from which I derived only temporary enjoyment and pleasure, but to be laying up for myself something more tangible for the great future before me. I was at a loss, for some time, to devise anything that was within my reach or circumstances.

We are all occasionally subject to loss of friends in this 
world, who pass to another and happier abiding-place; and though bereaved at parting with them, their departure always brings with it many beneficial lessons, not only as warnings of the inevitable result of all our struggles and triumphs in this life, but of the hope of a brighter home above. Upon such occasions it is the custom of presiding clergymen to attempt to rekindle anew within us a true sense of what we are, and to inculcate in our hearts lessons of a deep and moral nature. No person, perhaps, was more keenly sensible to such truth than myself, with the strong and naturally sympathetic disposition I possessed. I could not deny the deep impression it made upon me, when attending the last sad rites devoted to a long and cherished friend, for whose loss I had been called to mourn.

But these thoughts were not all which occupied my mind; for I was yet a mortal, and susceptible to all the scenes and incidents of a young and active life. I viewed with pleasure the affection displayed by the relatives of the deceased, in the neat and silver-tipped burial-case, made more heavenly and beautiful by the profuse adornments of flowers and wreaths, composed of many varieties which I observed were quite out of their season, and as I turned from the grave, musing upon the uncertainties of life and the vanities of this world, these facts became blended with the flowers I had just observed; for, like flowers, we spring up and have our day, we bloom and fulfil our mission, and 
then pass away from this earth to be no more. But flowers, I thought, are not always in season, and yet I distinctly remembered beholding these emblems of purity ofttimes before, upon similar occasions, when the chilling and howling blasts of winter were having their reign unchecked. From whence, then, were these immortals procured, since they could not live when all other vegetation succumbed to the ruling tempests? True, from the allwise and merciful Giver of all things; but it must be through the agency of man.

Seemingly shameful for man thus to gather his spoils from the dead. But a moment, - had I not seen them under other circumstances? The opera, theatre, and other fashionable resorts were favored with them in such abundance as to be cast at the feet of those to whom they would tender a mark of appreciation; and here was a lesson of observation, and, thus musing, I resolved to search out the human agency through which people were thus favored with such delicacies.

What was most strange was that I should for years have passed over the same daily walk, and given no more than a passing notice to the many signs of florists which hung out over my pathway. But now, I was a cultivator of the soil, and I was interested; before, I was blind and saw not. I ventured to make a call of inquiry, and the kind and genial manner with which I was received, and the free and willing manner in which they imparted all information desired, 
rather pleased me, and I said, surely these are not men, - so unlike the crabbed, selfish, and reticent persons with whom my life had been passed. No tricks of trade, and no secret with them which they feared to tell lest it should damage their interests, as among mercantile professions, did I find, as, one after another, their long glass houses I visited, filled with every variety of choice and rare plants. The more I saw, and the more I learned, the more I was pressed to venture my bark upon this stream. My lease would not. expire until April and I could easily continue my experiment upon another tack. It was the last week in September, and a little late; but, with speed, I was advised that I could succeed. From that moment I was a florist; but there was to be no might succeeds with me, for I was going to succeed. My first work, then, as a florist, wis to gather in all my articles not needed during the winter, and place them under shelter; then lay out my ground for the erection of a small greenhouse, the building and stocking of which would be my first and greatest expense. Plans of various kinds of greenhouses were consulted and studied out. Those which seemed most practicable were attended with an expense far beyond my means. I was, therefore, thrown upon my own resources, and planned my own way out. A greenhouse that should be cheap and good for a season was all that I needed, for, in all probability, I should have to remove it from the premises in April. 
It was the twenty-fourth day of September before I broke ground as a florist. The most requisite step was to mark out my ground to allow the greenhouse to stand north and south, the object being to give me a good southern exposure, thus securing the full effect of the sun's rays the entire day. I laid out a piece of ground forty feet long and eleven feet wide, which I contracted to have excavated to the depth of two feet for twelve dollars, including the setting of twelve common oak fence-posts ten feet apart on each side and two on each end. These I sawed off to within three feet of the level of the ground. Upon them I placed a skeleton roof, or frame of rafters. This left me a space of four feet between each, for which I ordered sash to fit, and attached every other one with a leather hinge that I might tilt them up when necessary for ventilation. The sides I then boarded up tight, and threw the earth up against them even with the eaves, to keep out frost. At one end I built a little workshop and potting-house, ten by twenty, and twelve feet high, making a little loft for storage. This was a skeleton, built principally of boards, and board roof, with the cracks battened up.

Here was my cosy little greenhouse complete in two days, and as I walked through it I thought it almost good enough to live in. Upon the inside I had five feet clear in height and four and one-half feet bench room on each side, leaving a passage-way of two feet. This gave me three hundred and sixty feet of bench room, and just room 
enough left to work with ease, but none to spare for visitors. I procured a large stove or heater, and placed it in the workshop and ran the pipes all around under the benches, at a cost of sixty-seven dollars.

But one thing was now wanting to make it complete for operations, which was water, and the means of applying it. The facilities of the city for this indispensable are not sufficiently prized, it being so easily brought into the house and into any room we like; but in this instance I appreciated the fact, and straightway availed myself of the privilege, and had pipes laid connecting with the main and brought it into my workshop at an expense of twenty-five dollars, and with hose so adjusted that I could shower all the benches in a very few minutes.

Believing everything now complete, I invited in Mr. Clarke, a florist, who had been exceedingly kind to me, to point out any deficiency I had overlooked. He acknowledged everything perfect, but suggested a coat of whitewash all over my glass roof upon the inside, as he said the rays of the sun would be more evenly diversified, and, besides, its sharpress sometimes would prove injurious. I adopted his suggestion forthwith, believing "an ounce of prevention worth a pound of cure."

My expense thus far was as follows:-

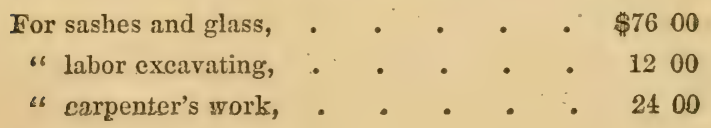


For posts, lumber, etc., - . - - . - $\$ 3500$

" heater and pipes, . . . . . 6700

" hose and water pipes, $\$ 20$; incidentals, $\$ 5,2500$

Total cost of greenhouse, . . . . . $\$ 24000$

This was my first and greatest expense, and the first of October found all in trim, although my pocket was somewhat lightened, and I had but one hundred and eighty-one dollars left as working capital. I was contriving to economize on my salary, and by spring seventy dollars from this source would be aidded to my capital. The days began to grow a little bleak, and the variegated colors of the foliage on every hand were but the forerunner of the cold and dreary winter yet to come. My castle was built, and what cared I for rude winter's chilly blasts? Time and tide wait for no man, and so I hasted away to stock my little greenhouse, under the advice and direction of my friend Clarke, the florist. 


\section{CHAPTER VIII.}

STOCKING OF GREENHOUSE - NEARLY A FAILURE - UNFAITHFULNESS OF HIRED HELP - TEMPERATURE - RUDIMENTS OF FLORICULTURE.

THE stocking of a greenhouse was at that time no small matter, as I was more green than any plant I might place in it. I must confess I had great diffidence and little courage after reaching this point.

$\mathrm{Mr}$. Clarke had taken great interest in my affairs, and did much in the way of encouraging advice, and occasionally dropped in of an evening to see how I was getting along. His favors, though seemingly small, were of material aid to me, and I have ever felt under many obligations to him. As it would be utterly impossible for me to raise plants on bare boards, my first step was to procure and make a soil in which to grow them. Before doing this, however, it was necessary for me to know what flowers I intended to cultivate; this depended again upon the wants of the plants, and the temperature they required, some requiring a heavier atmosphere than others; and having but one greenhouse, it was a matter of no little importance, and one upon which I could not act without advice. 
It being decided upon I proceeded to make a soil of the following proportions: Two good wagon loads of wellrotted compost, one of meadow muck, and four loads of fine sand, which I thoroughly mixed together, and spread about six inches deep in boxes about two feet wide, made by cutting in sections a lot of old soap-boxes, and then placed them upon the benches. I had also procured a load of fine broken stones, a layer of which had been put upon the bottom of the boxes, to act as a drain, and the bottom of the boxes perforated with holes to let off the water. The sum total expended for all of these articles amounted to just fifteen dollars. Another layer of white sand, about two inches, was spread over the surface, when it was prepared for the reception of my plants. My first invoice of plants was one hundred tea-roses for thirty-five dollars, and two hundred heliotropes for thirty dollars, and every day was devoted to setting them out. This work being accomplished there was considerable room left, for I had set them very closely together, feeling the importance of economizing room as much as possible under glass. I concluded to fill in, without overcrowding, and allowing for the increase of stock, a few more desirable plants, leaving violets until the last to fill up with. The following summary will give an idea of what my stock consisted, and their cost :-

100 tea-rose plants, for . . . . . $\$ 3500$

200 heliotropes, " . . . . . 3000 


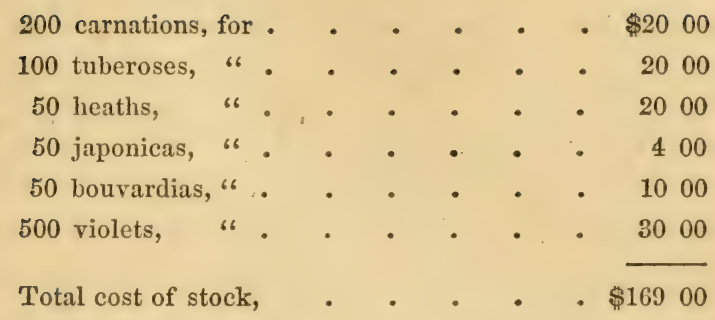

By referring to the cost of the greenhouse, it will be seen that the expense of building it had covered all the profits of the summer's labors within one dollar. The cost of stock for the same covered all the savings of my salary for one year within one dollar. According to the figures, then, there were left just two dollars as working capital.

The difficulty was somewhat obviated, the whole amount of cost of the plants purchased from Mr. Clarke not being required down, and which favor left about eighty dollars' capital on hand. This was quite a risk, although no greater in proportion than the risk taken in the summer, yet there was this difference: Flowers were a new and strange product, and I was not as confident of success in my undertaking as in the summer. My first effort met with very bad luck; for I had but just got everything set out, when I found my plants, some of them all wilted down, and came very near losing every one. Calling in Mr. Clarke at once, he saw at a glance that I had neglected to water them after transplanting thern. It was quite fortunate to 
discoverit, even at the last moment, and with the combined skill and experience of friend Clarke, I acting as his servant in everything, we succeeded in restoring them to life in a ferw days. Very fortunately, extreme cold weather did not set in until the last of October, and thus a greater loss was not suffered. I was immediately thereafter subjected to a sharp lecture from Mr. Clarke, upon carefulness and observation, which I shall never forget. It was worthy of emanating from a greater philosopher, and contained sentiments well adtapted to people of all classes of business.

Were it not for my poor memory I would give it in full; but, suffice it to say, I was forced to make up my mind that thereafter I would try and attend more closely to my business. The first few weeks were weeks of great anxiety, fearing lest again, by some little carelessness, some trifing attention might be overlooked which would be of vital importance to the little army of plants now under my control. One great precaution necessary was to have the right temperature at all times; and this was no easy task, as may be imagined, where such a variety of plants were growing under one roof, and nearly every one requiring a different grade of temperature. Large florists manage so as to have but one or two varieties in one house, and thus the temperature is more easily graded to the requirements of the plant. The temperature prescribed for heliotropes upon a sunshiny day is seventy-five degrees, for cloudy days sixty-five degrees, and sixty degrees during the night, 
- a variation from which of more than five degrees at any one time might be productive of sad results; while violets required but sixty degrees in sunshine and fifty-five degrees in cloudy weather, and some of my other plants called for seventy-five degrees in sunshine. Each variation, therefore, would require ventilation or increase of heat, thus making care and watchfulness the most necessary of all things. Being unprepared to accommodate all my plants in all their requirements the matter was compromised, and the temperature adjusted as follows: seventy degrees for sunshine, sixty-five degrees for cloudy weather, and sixty degrees by night. For variation of temperature at extreme end of the greenhouse five degrees were allowed, and the plants arranged in such manner as to bring those requiring most heat nearest to the heater, and those requiring least heat, such as violets, at the far end. A thermometer, accompanied by a card marked with these variations, hung at each end of the house for convenience and safety. This constant care required some person in attendance during my absence through the day, after the cold weather set in and fires had been started. During the night I slept in the workhouse, having a bed made up there; and, having accustomed myself to sleep with very light covering, if the temperature went down too low I was sure to wake. This was all very well arranged and carried out; but soon I found that faithfulness was not always to be had for money. The first boy thought more 
of play than attending to his business, and I was forced to make several changes, and thereby several times came near other losses. At last, a faithful boy was obtained; but having had my confidence so much shaken by the instability of his predecessors, I could not place as much reliance upon him as he was worthy of.

In some of my purchases there had been thrown in a few fuchsias, in which I took a special delight; for they were a novelty in themselves, and there were just enough to give experience in growing them, and add a little variety to my stock.

A few of the lessons I was obliged to learn, and which are, as they say at school, the "rudimentary principles" of floriculture, may not come amiss in this place. First of all is temperature, upon which I have already dilated at length. The next important is the proper watering of plants. It will not answer to dash a pail of water all around, as you would water a tree or vine, for these are delicate. It should be done by means of a fine sprinkler, attached to the end of the hose or watering-pot, thus resembling a drizzling shower or mist in its application. Neither should the water be too cold. When watering, it should be done thoroughly, and if in pots fill them full; but never water a plant unless it requires it, and then only in the morning, and when the sun is shining, if possible. About twice a week water should be used, previously saturated with guano, or some good fertilizer, and applied 
with a watering-pot. Another important item is the keeping in subjection all insect life, which can be accomplished in no better way than by fumigating once or twice a week. Tobacco is best for this purpose. Weeds will grow here as well as elsewhere, and too much care cannot be exercised to keep them clear, and the more carefully they are watched, the easier it will be to keep the plants in good order and looking well. 


\section{CHAPTER IX.}

MARIETING FLOWERS - WHAT THEY BROUGHT - RESULTS OF WINTER'S WORK.

THE first few weeks were necessarily weeks of great anxiety, unaccustomed as I was to the cultivation and growing of such delicate plants; and especially at a time and in a manner contrary to their nature, and knowing that the least amount of carelessness on my part might cast away all that had been ventured in them, which was truly my all.

Thus was my new-found occupation continually the source of much uneasiness and fear, and it was some considerable time before a feeling of perfect control in their management was given me. Gradually one after another of the plants sprang up into active life, and with them my confidence was slowly restored. As late as the first of November no returns whatever were received, and expense was still the ruling item, which was increased by the cold weather with which the month was ushered in, and the necessity of starting fires. Coal and wood, to the amount of twenty-four dollars, were laid in at once, and preparations for the winter blasts now upon me were fully made. 
In a few days many of the plants began to disclose miniature buds as signs of flowering. Among the first to unfold its colored petals was the violet; but these were few, and mostly some which were more forward in the transplanting. In the middle of the month I ventured forth to find a market, with a few flowers in a basket upon my arm.

These had been picked and thrown into the basket without much assorting, and, a market being found, I could scarcely get any price at all. The great detriment was the careless manner in which $I$ had put them up and in which I had offered them for sale. A good lesson was learned, however, and I received kindly the advice given about packing them in parcels, assorted, and all of a kind in a parcel. The next lot was sent in better shape, and met a more ready sale. In view of the approach of the holidays, a greater demand was apparent, and the prices were gradually rising. At this time it was a matter of no. little importance that I should have clear weather and sunshine for the development of my flowers, for without it I would have none. After a pleasant day, evenings were spent in the greenhouse cutting and assorting the flowers, which I placed in a basket, the bottom of which had been first covered with moss, and dampened. This retained the moisture, and kept the flowers in good condition until they reached the market. Travelling to the city every day, I carried my basket of flowers and delivered them in the 
morning, receiving the money therefor. After a cloudy day, having no flowers to cut, the time was devoted to weeding and other necessary work to assist the growth of the plants.

I append below one or two samples of what I carried to market nearly every day, from the first of December to the first of February. The following was marketed the first of December, and was as small a bill of flowers as I had during the winter. It consisted of :-

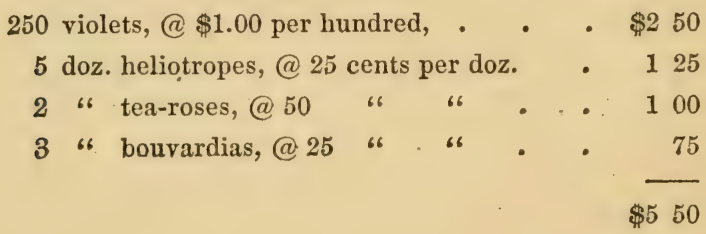

As the holidays drew near, and from that time until the last week in January; prices rose very high, and my receipts often ran as high as eighteen dollars and twenty dollars per day, depending, of course, upon the quantities I brought. It was necessary to exercise great care, so as to bring a good and salable assortment each day. Many of the little details connected with their culture, and the manner of treatment of all the plants to favor and develop them and bring out the flowers, would not be admissible within so limited a space. A good florist, of experience, to advise with is more preferable in this case than any book-theory, and I must content myself, therefore, with giving the ac- 
count of my success, rather than attempt to give the details of my work.

The following is a copy of a bill sold January fifth, and the largest in amount I disposed of that season:-

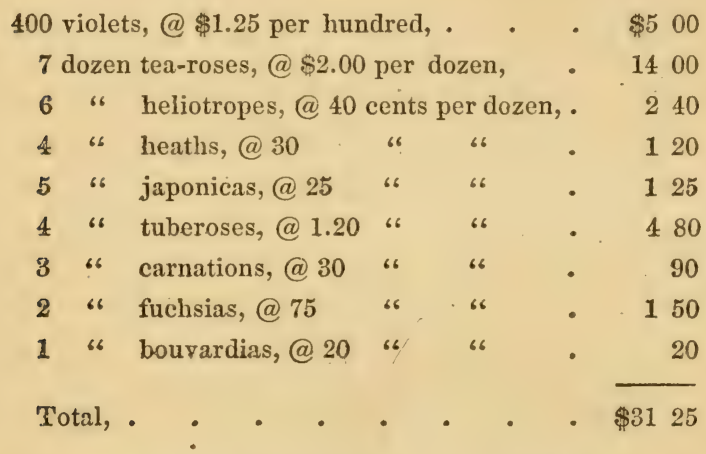

My average daily receipts for the entire two months was $\$ 648 \frac{3}{8}$. This was without any allowance for expenses. There seemed no particular limit, which could be depended upon, with plants, as to the number of buds and flowers each would yield, neither do all plants yield alike. Some bear profusely, and others notat all; while many of the same kind will bear flowers, and others will bear none at all ; as an instance of the latter, not more than one half of my tea-roses yielded any flowers at all.

A tea-rose plant will generally give from six to twenty buds, if any at all. Carnations yield from ten to fifty, and bring from two to four cents each. Nearly all plants must have their appointed season of rest. Even as man. 
requires sleep, so the vegetable kingdom must have its repose from labor to prepare it for future healthy and vigorous life. Flower-bearing plants, if cultivated in the summer, must rest in winter, according to the all-wise dispensation of Providence; and, to perfect this natural law, plants cultivated out of season must rest in season; and that this work may go successfully forward great care is necessary, to put them in a proper condition to keep them and retain them inactive and healthy. As the plants in the greenhouse had nearly closed the labor I had forced upon them, I was now long and busily engaged in remoring the bulbs and roots, and preparing them for rest while I introduced bedding plants, for transplanting early in the spring to open ground. I had at this time no idea of giving up my ground the coming summer, thinking I could re-lease it without difficulty, and proposed to have plants much earlier than the previous season.

My expenses and receipts from the flower business stood as follows:-

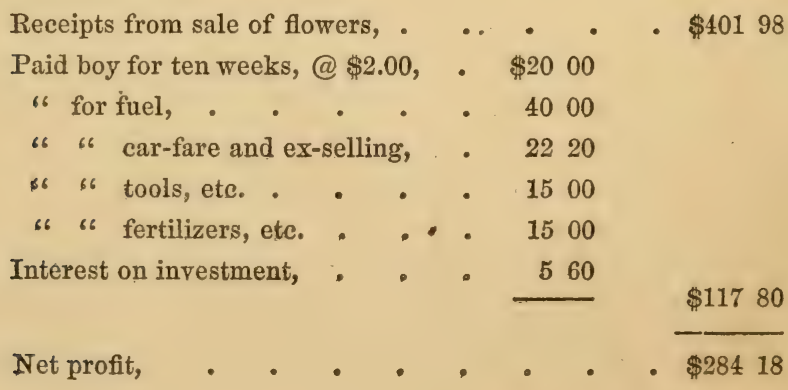

- $\$ 40198$ 
Thus closed my winter's labors quite satisfactorily, with a greater gain than had I been idle; besides, I had the advantage of a greenhouse for propagating my early budding plants. 


\section{CHAPTER $\mathrm{X}$.}

BEDDING PLANTS - SPRING WORK - SUMMER CROPS - SECOND YEAR'S BALANCE.

Bx the first week in February my greenhouse benches were all cleared, the bulbs all stored in a dry place, and potted plants set aside for the season. The next work was that of removing the soil upon the benches, which was followed by the sowing of lettuce and tomato seed. As there was room for much more than would be needed for my own use, I should have a quantity of plants for sale in the spring, which would bring me in a few dollars, in addition to which would be an amount saved equal to what I had been out of pocket for the same plants purchased the previous season.

It is a farmer's rule never to buy what he can raise himself; and the same rule would be applicable to all kinds of business with much success. A wise philosopher has said that a penny saved is two pence earned; but alas! how few appear to follow this rule! With eager interest I watched for the first signs of life from the seeds I had sown, and a week's time was sufficient to gratify my anticipations in that respect. 
Until they took good root, not much care was required to keep the weeds under subjugation. About the first of March I began to thin out the smallest, thus allowing those more forward to mature more rapidly, and to a greater perfection. By the first of April I had as fine a lot of plants as I had ever seen; and as far superior to what I purchased the previous spring as anything well could be. I at once advertised my plants, and found a very ready sale for them. Many persons came the second time, and sent others; while many purchased double the quantity they had intended, because they looked so well, as they would say; until I was unable to supply the demand without robbing myself. Being also about the first in market, I had a great advantage over others. My lease was now expiring, and I must enter upon some new arrangement, if possible, and this was a fitting time while my stock could be disposed of readily if necessary. It had not entered my head, however, that I could not secure my ground another season.

What was my surprise, then, when, upon applying to my landlord for a renewal of my lease, I received a flat denial! His only excuse was, he intended to build in the fall, and did not want me in the way; after some considerable persuasion, however, I secured a lease until September first, by paying seventy-five dollars for the six months. From my greenhouse I had sold five thousand tomato plants at fifty cents per dozen, and two thousand 
lettuce at twenty-five cents per dozen; leaving an abundance for my own use.

Reviewing the labors of the previous season and their results, and knowing my plants were so advanced as to bring my truck into a much earlier market, and also having in view the limitation of my lease, I resolved to rest my labors with the two crops, lettuce and tomatoes, and perhaps sowing turnips as an after crop.

The same labor was required, the same difficulties to be met, and the same obstacles to be overcome, and just as many weeds to fight this season as last. The weather was more dry, and to meet this I brought the hose from my greenhouse into active service.

I had discharged my boy, and hired a man, upon the first of May, at fifty dollars per month. The yield of my crop was perceptibly no larger this year; but with increased facilities and.more help, with more advanced and better plants, I was enabled to reach an earlier market. The first marketing was fully two weeks in advance of last year, and five hundred heads of lettuce brought me twelve cents each.

My greenhouse was filled with a fresh supply as soon as the first were sold, and then I transplanted to open ground as fast as I sold my crop off, which brought me a fair second crop; a second marketing of fifteen hundred heads brought eight cents each, and five hundred more subsequently brought five cents. The second crop brought 
me two cents each for two thousand heads. Early in Junc I had marketed one hundred baskets of tomatoes at one dollar and seventy-five cents per basket; a week later, another hundred brought me one dollar; the balance I sold on the vines for twenty dollars. By the middle of July my grounds were all cleared and sowed to turnips, the last crop of the season.

At this time I discharged my help, as a matter of retrenchment in expenses, and worked out the rest of the season alone. My operations on this little farm were now drawing to a close, and soon I must bid adieu to this familiar spot, after two seasons of the most pleasant and encouraging associations of my whole life. Here had I nourished my cherished plans into action, and brought them to a successful issue. I had clearly proved something could be done to alleviate my condition by my own exertions. It must be carried further, but not here; a new field with wider scope I must find, and devote myself anew to more extended labors. At this point it is perhaps most fitting to sum up the labors of these two eventful years in my history, as I draw to a close the scenes in and about this little half-acre plot, every portion of which I had learned well to know. Starting then with the balance I had on hand at the close of my first year, I give my 
SECOND YEAR'S TRIAL-BALANCE.

Balance from first year, .

Sale of flowers,

- $\$ 40198$

" bedding plants, . . . 37800

"6 lettuce, . . . . 26500

" tomatoes, . . . . 29500

"6 turnips, . . . 2800

Salary, . . . . . . 80000

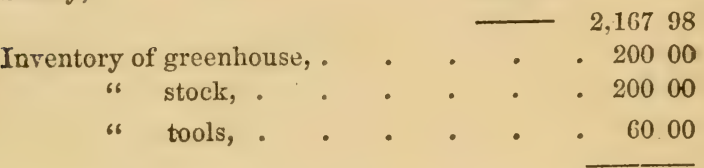

$\$ 3,00912$

EXPENSES.

Cost of greenhouse, . . . $\$ 24000$

" stock, . . . . . 16900

" running greenhouse, . . 11780

" for fuel, . . . . 2400

" " seed, . . . . 1500

“ "fertilizers, . • . 3500

" " ploughing, . . . 500

" " 100 new baskets, • . 2000

" " labor $2 \frac{1}{2}$ months, • • 12500

" " transportation, . . 1500

" " rent, . . . . 7500

" " books, papers, etc., 2300

Wear and tear of tools, . • . 2800

Interesi on investment, . • . 1256

Personal expenses, . • • . 64752

Amount of balance, . . . . $\$ 1,45724$ 
Amount of balance brought forward, $\$ 1,457 \quad 14$ Deduct savings for 1 year, . . 15244 " balance on hand first of year, 38114

Net profits over expenses, . . $\quad \$ 92366$

By the above statement it will be seen that the last year had exceeded the first by five hundred and forty-two dollars and fifty-two cents; but as over six hundred dollars were the result of my greenhouse in flowers and bedding plants, this would make the comparison in yield lower than the previous season. At this time I had nearly fifteen hundred dollars in hand, and was just that amount better off in the world than eighteen months before, or I would have been if I had remained plodding on in my old accustomed way at my business in New York. Again, it will be seen, my net proceeds were just one hundred and twenty-three dollars in excess of my yearly salary, and all of this from a half-acre lot, by the exercise of a little gumption and forethought. While I regretted parting with my half acre, so much endeared to me, I could not upon the whole say I was really sorry. It was evident the time had come when I was to choose between two callings.

The latter had proved itself able for my support in as good style as my salary had formerly given me, than which for the present I would ask no better. 
At that time my support was the all-important question, and which is clearly the vital question to all persons of small means; for it is necessary, when among strangers in a strange land, to know first how we are to live before we can afford to speculate or take any risks. Having this point accomplished, I felt confident an all-wise Providence would continue to guide me safely to the end.

A larger field I must seek, and rely solely upon my labors, for I could not longer hold my position in the city, and give this business the attention which it merited.

I had quite a little stock in trade, besides the greenhouse, which had cost me two hundred and forty dollars. All could be taken with me, except this, at a little expense. To move the greenhouse would cost me a hundred dollars, and an offer of two hundred dollars from my landlord was accepted for it. My stock of flowering plants had increased until they were really of more value than invoiced. All in all, all is well that ends well. 


\section{CHAPTER XI.}

REMOVAL - HUNTING UP A FARM - A FIVE-ACRE PLOT-PEOPLE'S CURIOSITY - A CRYSTAL PALACE - IAPPY HOURS AND THOUGHTS.

UPON the beginning of my third year, my first duties were to look up a farm suitable to my wants, which I found no easy task. When I set out upon my search, I found a surprising number of farms, all for sale; but most of them were too large for my limited means; while every small place of three or four acres, that was in any way eligibly situated, was held at a high figure, and so improved in many cases as not to meet my wishes. It was a curious circumstance to notice how eager every land-owner was to sell, and to hear the many absurd reasons for selling. The quantities in market were enormous, and real estate agents were abundant, with large books filled with descriptions of elegant country-seats and farms for sale. Some could be had for one-fourth the money down, while others were ready to exchange for city property, merchandise, or other traps. It seemed as if they all wanted anything rather than a country place on their hands. But one thing I saw very plainly, that they were anxious to get a better bargain than they had to give. City merchants, thriving 
mechanics, clerks, and even country-bred people who had accumulated a little surplus money, seemed to think the city was their only proper sphere. Many gave as reasons that their wives were not suited. How nice it is to have a wife's opinion to fall back upon, rather than boldly shoulder the responsibility one's self! Some found farming did not pay. Others had taken land to secure a debt, and wished to sell to realize their money; others, tired of country life, wished to embark in business in the city. Change of some kind appeared to be a monomaniac idea running rampant with all the country people; and this was not surprising when real estate was bringing such high prices. It gives me pleasure to say, however, that there were some who appeared to appreciate country life, and who could not be induced to think of selling. There were apparently two streams of emigration, one to the city and another out of it; but the former much exceeded the latter. Certainly they had never experienced the perplexities of maintaining an existence in an overcrowded city. Yet with all this I was not discouraged, nor to be thwarted in my plans. My lease had expired, and my stock was turned out of doors, which must be speedily sheltered or else be lost. The past year had proved my business adequate to my support, and as well might I go a distance as hover in the vicinity of the city. Accordingly I cast myself loose from my business in the city, and started out fifty miles away into the interior, 
among the green-clad hills and dales of old Connecticut, where, fortunately, I found just the spot I had long been searching after. It was a little farther from market than I had anticipated; yet it had a railroad with several trains a day, and was only two short miles from the sound, down which ran weekly two market-boats, making the trip in twenty-four hours. This was a desirable means of shipping produce, than which, combined with the facilities of the railroad, I could ask nothing better. The tract consisted of five acres, all tillable land, and was the portion set aside to the wife of a well-to-do city merchant from her father's estate. After much talk I bargained for the place for six hundred and fifty dollars, two hundred dollars of which was to be paid down, the balance within three years, with interest. It had upon it one solitary house, which was rapidly going to decay and ruin, and an old shanty, which had been used for a horse and cow, being filled to their knees with old compost. It was a hard sight; but it could be made very acceptable. The day I entered into possession I cast my eye around, and saw so much to be done that it was with difficulty I could determine what to commence upon first. I was now my own master, and lord of all I surveyed. Happily, the little furniture which I had owned several years, and used in furnishing my own room while boarding, came in good play, and I at once set to work to domesticate myself in the old house.

Thanks to a kind mother, who had taught me when a 
boy, the manner of preparing food, for thereby I was enabled to bring it into practice to advantage. With abundance of time, the duties were easily performed; and if ever there was a hermit and a bachelor, there was one in that old house. This answered very well for a few weeks; but I began to feel out of my sphere, as work out of doors drew more liberally upon my time, and I was induced to secure a house-keeper.

My first day's work was performed in the kitchen-cellar, cleaning out old rubbish, bottles, and decayed vegetables, to make it a fitting receptacle for my stock of plants. This was really the hardest day's work I had; for my ambition led me to such an extent as to work beyond my physical strength; and a lesson I learned, that, if I would last long, life must be taken more easily, and labor according to my strength.

Lumber and material for my new greenhouse had been ordered before leaving the city, and came with my other goods, together with sashes of a proper size. In a word, I had duplicated the greenhouse previously built, only, instead of one, I should build three side by side and one hundred feet long, with a potting and workshop upon the end. These I erected entirely alone, thereby saving some expense, and reducing the cost of the greenhouses to six hundred twenty-eight dollars. My stock of plants had so increased as to occupy one whole greenhouse and one half of another. To this stock I added twelve varieties of verbe- 
nas, true to name, calculating to propagate the plants from them for a spring market. Particulars of how I managed them will be given in another chapter.

Having moved into a neighborhood of entire strangers, I found them much more congenial companions than I had expected. Their curiosity was unbounded, surpassing, apparently, any other faculty they possessed. A country town is much given to gossip; and not alone is it confined to the old ladies, but the men take up the cue, and few there are who do not only know all their neighbors for miles away, but everything in regard to them. I was a new-comer, and, of course, was the subject of general inquiry for a time. The people among whom I had come wère a sturdy set of old-country people for generations back, with strong, puritanical ideas; following a long and safe distance in the rear of all improvements, believing their old ways best, until others were well tried; caring well for every penny, and loth to take any risk, unless a sure return was clear to be seen. They had lived on for years in the same old routine as their fathers before them; cultivating onions, potatoes, and grain, year in and year out. To them the new-comer was of no little importance, and as they drove their ox-teams by, they must come to a dead balt, step in, and have a talk.

The building of my greenhouse set their eyes all wide open; and upon me they pronouneed every lind of benediction but success, and turning away, shaking their 
heads, they said, "Surely I was a very rash young fellow, putting so much money at so great a risk in these glass houses, from which I could never get returns for my labor. They had always heard the city folks had wild ideas, and, indeed, I was a novelty. Why, this beat anything they had ever hearn tell of, and they wouldn't believed it, until they had come and seen it for themselves." I could not resist the temptation to laugh at them, for I paid no more heed to them than to so much wind; and I kept jogging along, first with hammer, and saw, and plane, until I saw the completion of my crystal palace; then the fertilizers, with shovel and trowel, were brought into action, and my plants set out, bringing all of my past experience, with suggestions of reason and judgment, to bear upon my work. This work completed, every day brought with it something new to do; and I experienced a just pride in fixing up every convenience, and making all improvements within my power around my new home. I felt a degree of satisfaction unparalleled, in being the owner of my own ground, and felt that my labor was not lost. My mind was fully occupied, and thus happily days wore away into weeks, and weeks into months, through thick and thin, and bitter cold, until spring dawned, apparently before its time. 


\section{- CHAPTER XII.}

SALES OF FLOWERS - CULTURE OF THE VERBENA - CUTTINGS - ROOT CUTTINGS - PROPAGATION.

The season kept open late into November this year, and favored me in not requiring fires and in a saving of fuel. In attentions to my plants I was favored with my past experience, and strove to remember all the lessons of friend Clarke; for he was not near at hand now to run to in cases of emergency. My education as a florist was in no wise complete, although a winter's work added many new facts to my store. The advantages of having daylight to work by were many, and duly appreciated; and many otherwise idle hours were devoted to study and observation.

With the middle of December came my first lot of flowers, which were carried to market in person; and from this time until the middle of February, my average siles of flowers were eleven dollars and thirty-three cents per day. As before stated, I had purchased a small stock of verhenas, and devoted much time to their propagation. It was with some difficulty I found that these could be successfully cultivated, and I had entered upon an under- 
taking far more serious than I had anticipated. With a good stock to commence upon, cuttings were taken from the most healthy plants. Each was placed in small pots, and left to root. I soon noticed the soil in the pots. became dry very quickly. I showered them plentifully with water, and then they became very dry, rather baked in appearance. If allowed to continue, this appeared to injure the growth of the plant.

Then I was really puzzled as to what was best. Being in the city one day, I ran over and secured a little advice from old friend Clarke; and when I returned home the plants all came out of the pots. As quick as ever it could be done I made a soil, covered mostly with pure white sand, right upon the benches, which retained more moisture a longer period, and kept the soil well soaked with water the first few days. More depends on carefulness if one would propagate successfully, and a man who has had the management of a greenhouse for a season, with his eyes and ears 'open, will acquire a better theoretic and practical knowledge than could be obtained through the medium of books; and, if of fair intelligence and naturally observing and studious, he can operate with success. For an amateur, the next best thing is to have some good friend of experience to advise with frequently.

It is suggested, by an experienced florist, that the bottom of the beds should be spread thrce or four inches with refuse hops, tan-bark, or some such material well 
beaten down, and over this two or three inches of sand, giving, as a reason, that passing the heat through them from the steam pipes, which should run along under the benches, the heat becomes modified, and approaches more to that of the hot-bed. Although I agree perfectly with this writer, I did not at this time follow that practice, but simply spread my benches with sand from six to eight inches deep. Cuttings root freely from slips taken from young wood; but great importance should be given to the proper time for taking them. I think I may safely say that if a soft-wooded plant is bent, and it should break off brittle, it is then fit for cuttings; if it bends, it is then too hard. It will root, but more slowly, and will not be likely to produce as healthy and vigorous a plant. Many florists claim cuttings must be made at a joint; but in my experience $I$ have observed the above rule to be of the most importance.

Having prepared my bed of sand in one of my three houses, I raised the temperature of the soil to sixty-five degrees, which was indicated by plunging the thermometer into the sand, to correspond with which the atmospheric temperature was kept fifteen degrees less; with a range of five degrees higher or lower; but I kept as near to sixty-five degrees bottom heat and atmospheric temperature as near fifty degrees as possible at all times. Moisture and temperature are the two principal conditions upon which the prompt and active life of the cuttings 
depend. In a few days there formed at the bottom of the cutting little bulbs, which I took out, and divided the end of the cutting into little pieces one-half inch in length, which was covered with these bulbs, and spread upon the propagating bench, covering them with about one quarter of an inch of sand. These were now what is called root cuttings, which process helps to increase the plants more rapidly than they would from simple cuttings. From the time these cuttings were first set out, until the root cuttings began to spring up, I never allowed them to get dry; and the more thoroughly I kept the sand soaked, the more successfully they came forward. If a cutting once gets wilted, its juices are expended, and it becomes worthless for propagating, and only tends to invite the black rust. This excess of moisture only appeared necessary in the propagation of the verbena. By shading and good ventilation they are less liable to become wilted. Shading is effected in different ways, by different florists, every one claiming his own way the best.

Some use canvas thrown over the glass, or bark-matting; some whitewash their glass. A very good way, though involving some labor and expense, has been recomnaended, which is to make screens of common lath, nailed one inch apart to frames made to fit the sash. The least expensive for me was the process of whitewashing, which process I have always followed, believing it fully as practicable and efficient as any. 
In about ten days the cuttings were all rooting fincly, and then commenced the process of potting them off in pots, two and a half inches in diameter. The small roots, from one to one and a half inches in length, grew better, and produced finer plants than those allowed to grow longer. The latter became woody and hard, and did not strike down into the soil as freely as the others; after which observation I concluded that it was a fact, of no little importance to the propagator, that the earlier they were potted after rooting, the better. After they were potted they were set on a bench, covered about two inches with sand, and freely watered for some days with a sprinklingpot, and treated in every way as if they were still on the propagating bench. If at this point they are allowed to wilt from drying, or excess of heat, they are liable to be sickly plants, and more susceptible to disease. As soon as these cuttings appeared to have taken root, and showed signs of life, I took care to keep them cool and abundantly supplied with air, by putting up or letting down the sash, keeping the temperature about forty to forty-five during the night, and ten degrees higher during the day. As soon as they acquired the proper condition, I again converted them into cuttings, and repeated the process, - thus continually increasing my stock.

One of the greatest drawbacks to the cultivation of the verbena is called the black rust. This enemy, properly defined, is the verbena mite, - an insect so 
small that it cannot be seen by the naked eye, and when it has once gained a foothold, it seems to defy all efforts to dislodge it. The fumes of tobacco, so destructive to all others, seems to fall harmless upon it. It has the power of imbedding itself in the leaf, and resists all attacks. The only remedy $I$ have found is to keep the plants in a healthy and vigorous condition, and thus the plant is enabled to repel it. Whenever a sickly plant appeared I would cut it off, thus forcing a greater amount of the succulent juices into a smaller space, thereby increasing the strength of the plant. If I did not succeed thus in restoring the plant to a healthy condition, it would come out root and branch.

Continued fumigation is of the utmost importance in the culture of all plants under glass, but perfectly indispensable in the case of the verbena. It was my practice to fumigate all of my houses at least twice a week, and sometimes oftener, as a preventive to the aphis or green fly, which is very destructive. The ground or blue aphis is a very dangerous pest, its field of destruction being the roots, at the end of which it affixes itself. The only remedy for this is tobacco-water, about the color of tea, applied around the roots once or twice each week. 


\section{CHAPTER XIII.}

EXPENSE AND PROFITS OF GREENHOUSES - PURCHASING STOCK - BAD

BARGAINS - KINDNESS TO ANIMALS - SPRING CROPS - A CONTEST AND VICTORY.

ANother spring brought the same work as previous seasons, though now much increased; and by the first of March my flower-bearing plants had all been examined, and carefully put away. I renewed the soil in my greenhouse, then cleaned and sowed cabbage, tomato, and lettuce seed, passing them through the same treatment as in former years. Though but a small number of verbenas at first, their rapid increase by propagation had not only more than filled the space I had allotted, but even went so far as to deprive me of much room I had anticipated for bedding plants; therefore I should have none for sale this season.

The expenses of my greenhouse were larger this year, because I had tripled it in size. Being almost constantly present myself, and when absent leaving it in charge of my house-keeper, I obviated the expense, as well as the risk, of a hired boy to watch it. The cost of my fuel and fertilizers was not as large, being but double that of my 
old greenhouse. In building the new greenhouse, I had substituted a steam-heating apparatus, - the cost of which is estimated in the expense of building, - which had steam pipes running under the benches, and gave a better heat at a less expense; for it hardly required any more coal than the old stove-heater, and gave a more even heat to the whole three houses than the old stove had done to one. My verbena plants were removed, soil and all, from their little pots, and placed in a small chip basket with a handle, one dozen in each, and each basket containing twelve kinds. When put in baskets, without naming them, I sold them at wholesale, for seventy-five cents, they retailing for one dollar. Great trouble and much time were required to write names, and place them by each kind, and for these a better price is received, they retailing for one dollar and fifty cents each. I sold verbenas, named, at wholesale, for one dollar per basket of one dozen each.

Briefly summing up, my expenses for running the greenhouse this season were as follows:-

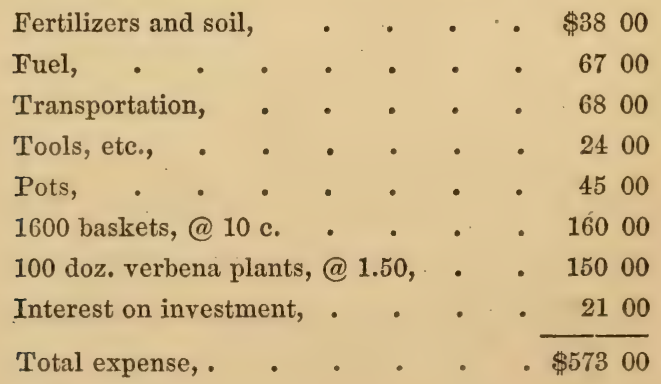


My stock of verbenas cost the full price, as I bought them all named, and by their propagation I had made the wonderful increase which enabled me to sell sixteen hundred baskets, or dozens. I should judge about one quarter of that number had been pulled out and thrown away, from being sickly or otherwise injured. My receipts this season from the greenhouse were as follows:-

Sales of flowers, gross amount,

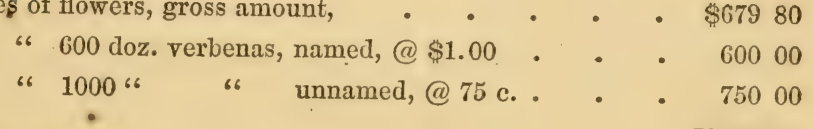

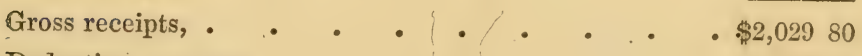

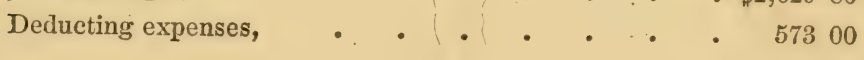

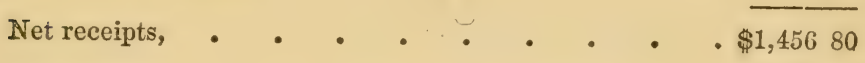

Figures look very large in gross view; but did space permit, every detail might be more explicitly given, and it would not then appear so fabulous.

My work in the spring was somewhat enlarged, and, to facilitate it, and for other work that might occur, I deemed it necessary to purchase a span of horses; and for this purpose I laid out two hundred and fifty dollars for a team, including one set of harness and a light wagon for ninety-five dollars. In other tools, - such as a plough, for ten dollars; cultivator, three dollars; harrow, three dollars, and other things, five dollars, - I supplied myself. I started ploughing as soon as spring opened, which was not 
until the second week in April. I had overlooked the fact that my location was among the stony hills of Connecticut, and that I had anything more to do than plough my land; but I soon found it was folly to plough until I had first built a stone sled of two thick planks, and spent nearly a week in picking up and drawing off the stones upon my ground. These I found very acceptable in repairing several breaches in my fence. The yield of stones in some sections of the country - of which this seems to be a fair sample - seems to be inexhaustible, yet, when laid up in a good fence, become very useful and durable. Having ploughed my land, and harrowed it twice over, I proceeded to divide it into acre plots, one of which I planted to potatoes, one to tomatoes, one to cabbages, and one to lettuce. The remaining portion I devoted to a vegetable garden for my own use, and fodder for my horses. Being desirous of building up my family, and entering into the realities of a farmer's life, as well as desirous of availing myself of the privileges accruing therefrom, by purchasing a few forls, a pig, and a cow, costing altogether one hundred and fifteen dollars, - I seemed to have all that was necessary in the way of stock. With my own hands I built a temporary barn, with accommodations for the above-named tenants, at a cost, for material, of twenty-six dollars. My neighbors appeared now more hopeful, believing I had taken a few sensible steps for the first time during my sojourn among 
them; but the story of the profits from my greenhouse those quaint old people could not exactly believe.

I cannot say that I always made good bargains in ail my purchases. One of my horses proved to be very balky, and, as I was afterwards informed, had always been so, and the seller knew the fact when I purchased him; but, with true Yankee shrewdness, said nothing about it, because it did not occur to me to ask him. Moreover, the animal had always been treated in the most inhuman manner whenever he was disposed to manifest this bad trait in his character. He balked several times with me at first, and I noticed he always awaited his accustomed pounding with fear and trembling. Not believing in maltreating a dumb animal of any kind, his anticipations were never realized at my hands. Whenever he showed the disposition of not performing his share of the work, I would lay down the reins and pat him a little, putting my arms around his neck, and talking to him gently and kindly. The vicious look in his eye, on such occasions, would soon pass away, and his actions would then speak, as plain as they well could, his appreciation of my kindness. After that it would need but little coaxing to persuade him to perform his work as willingly as ever. This treatment finally cured him, and he has never balked once since the second month I owned him, and is to-day one of the best working-horses for miles around. So much for kindness to dumb beasts; 
and I believe it is invariably the shortest road to the desired end in the management of all animals.

The season opened very stormy, and it really appeared as if it was all rain and no clear days for over a month. Plants grew, and weeds grew more; everything grew very fast, and grew vigorously. I laid out two hundred dollars in manure, and worked hard to get everything in order, in the face of the weather, and all other discouragements. These frequent showers not only dampened the ground, but also dampened my feelings very much. All things looked decidedly blue, and I felt very much like throwing up all I had undertaken. In conversing with the neighbors, I found sympathy; for they all felt the same way. I was careful, however, to show no discouragement in their presence.

Every cloud has its silver lining, they say, and soon April showers brought their career to an end, and old Sol once more bestowed upon us all his beauty, warming all things into life. Then began the fight with weeds, and a sharp contest it was. A week's work brought me so little headway that I persuaded myself to go straightway and hire two men for thirty dollars a month and board. With horse, cultivator, and hoe we soon made sad havoc among the weeds, and as often as the whole farm had been gone over the process was repeated, until everything was beyond the power of injury within the reach of weeds. The more I stirred the ground, the more rapidly all things 
grew. New work came in by way of staking, and tying up the tomato vines, for already their slender support yielded under their own weight. This was all work and expense for some weeks; but, with the opening of June, lettuce became fit for market, which must be furnished means of transportation, and many preparations for other coming crops engrossed my attention. I had no lack of sufficient ways to occupy my whole mind, and yet at no time felt overworked. Out-door exercise continued to agree with me perfectly, and was more plainly to be seen in its effect upon my health, weight, and appetite. Summer days came as a respite to the cold and dreary days of winter, which seemed to be enjoyed even by the birds, for their musical notes always caught my ear first in the morning and when the day passed into night. 


\section{CHAPTER XIV.}

CLOSE OF THIRD YEAR - TRIAL-BALANCE.

IT will be unnecessary for me again to mention the details of the work and growth of my crops during the summer, for they were not materially changed in the method of their growing, nor was there any difference in the nature of work required, although it was greater in amount, and required more labor to accomplish it as efficiently. Reviewing my work from the first of September, I found I had been to a considerable expense, from moving and providing new stock and necessaries, which went to expense account, and all tending to reduce the actual amount of profits. The amount of cash I had commenced with was more than exhausted in those outlays, and which in coming years would stand to the credit of income, if I met with similar success. Among these expense may be named the first payment upon my new place. The house, although needing repairs, had been allowed to remain unimproved, except so far as my own labor was brought into requisition to make it comfortable. My greenhouse and verbena cuttings were an actual out- 
lay, as well as my horses and live stock, - which would not again have to be supplied, - an entire new outfit of tools for my work, a few household articles needed to make a comfortable abiding-place in-doors, and the necessity of a house-keeper,- - all of which tended to swell the expense account. You who are married might do much better; but, as I lived a life of single blessedness, I was compelled to pay for this blessed privilege. With my winter work I had been fully satisfied. My verbenas succeeded and multiplied plenteously, and another winter I was disposed to make verbenas a specialty. The stock of other flowering winter-plants had increased nearly twofold, and yielded me a better return than ever, although some were lost entirely. My facilities for market, as before stated, were of the best. Some extra expenses were incurred, however, in the way of commissions to the agent in the city to whom I consigned my produce to be sold. The prices given below are the net amounts received after deducting freight, commissions, and other expenses.

A difficulty, not before known to me, was experienced in the negligence of my agent in not returning all the baskets in which the produce was forwarded to market; but I learn that it is no unusual case, and that all shippers make an allowance for it, calculating that if half the baskets are returned, they are doing well. My first shipment was three thousand head of lettuce, which reached an early market, and brought me ten cents net. A sub- 
sequent shipment of four thousand head brought seven cents. They had the good fortune to all reach market in prime order, and thus met a ready sale and good prices. The market soon after became liberally supplied, and two subsequent shipments closed up my crop, and brought four and two cents each, of two and one thousand each, notwithstanding they were more mature and better in every way. My lettuce crop was hardly disposed of, and the ground cleared up, before my attention was directed to the gathering and shipping of tomatoes. The plants having been pretty well advanced when transplanted to the open ground, they came forward quite rapidly. The soil had been made very rich, producing a very good effect, both in the early crop and the quantity. The yield was about four hundred baskets, which were put up in the usual peck basket, and brought prices ranging from one dollar and twenty to fifty cents per basket. The balance of the crop I sold on the vines for twenty-five dollars. Succeeding tomatoes in prompt rotation came the cabbages, bringing from four dollars to two dollars per hundred. Potatoes were a later crop, and the average price received per bushel was one dollar and fifty cents. I had planted a very early variety, which brought a very fair price for the times. At the present writing, potatoes do not reach these figures, and the price received was owing to the state of the market consequent upon the demands of the war then raging. The following recapitulation of my 
year's work will not only be interesting, but will bear verification :

Cash on hand beginning of the year, . . $\$ 1,45427$

Sales of flowers, . . . . . . 67980

" " verbena plants • . . . . 1,35000

" " lettuce, . . . . . . . 68000

" " tomatoes, . . . . . . 1,15500

" " cabbages, . . . . . . 16400

"6 " potatoes, . . . . . . 60000

Inventory of greenhouse, - • • . 60000

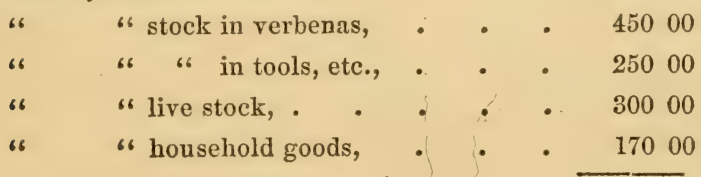

DISBURSEMENTS.

Paid on land, . . . . . . $\$ 20000$

" for moving and freight, . • . . 2000

" " household furniture, • . . 17500

" " salary to house-keeper, • . . 15000

" " expense of table, • • • • 4400

" " clothing and incidentals, . . . 25000

Cost of greenhouse, • • • • • 62800

" " running the same, • • • • 57300

"6 " seed, etc., • • • • • . 1500

" " span of horses and harness, • • 25000

" " wagon, . . . . . . 9500

" " carm implements, . . . . 2100

" " cow, pig, and hens, . • . . 11500

"6 " manure, • . . . • . 20000

Carried over, . . . . . . . $\$ 3,10800 \$ \overline{\$ 7,85307}$. 


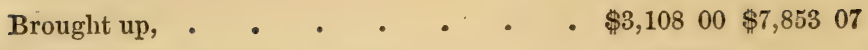
Cost of two men three months, - . . 18000
6 " 200 new baskets, . . . 4000
3,32800
Amount of assets, . . . . . . . . 4,52507
Deduct amount on hand beginning of year, . $\quad$ - 1,45ั4 27

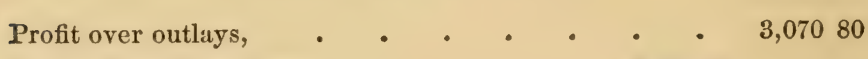
Adding payment on land, . . . . $\$ 20000$
" expense of greenhouse, • . . 62800
" " . . . . 84600

1,67400

Net profit for third year, . . . . . . $\$ 4,744$ SO

At first sight these figures look rather large, and I dare say that many, upon reaching this point of my story, will put it down as unreasonable and improbable. It is not at all fabulous to me, for I worked side by side with these figures, and I know the work was worthy of the result, and even more.

System was one of my great plans in all my work, and my account-book was brought out and entered up as regularly as I wound my watch or nightly retired to rest, and thus accurately kept. These figures are bona fide, and copied from that same account-book. Allowing, if you please, one half of all these to be true, there is still left sufficient evidence of success to guarantee any person to engage in a similar enterprise.

I had opened my new farm just at the close of the war, 
when prices had scarcely began to take a downward course, and this, together with promptness in reaching an early market, secured me fair prices, and as quoted. "Oh, war prices were profitable; but it could not be done now," it may be said. It may or it may not be so; but indications at the present writing are strongly in favor of the latter.

It would be far from my desire to overstate any case or probability, rather preferring to underrate, if anything; and I have tried to make clear my statements. I know there is a great tendency among the reading public to slur at such statements, and I can only ask an impartial judgment. 


\section{CHAPTER XV.}

CITY AND COUNTRY LIFE CONTRASTED - ONIONS - HOW RAISED PROFITS OF CROPS.

After a successful harvest I had no reason for not congratulating myself. I was now fully established in the country genuine, and was favorably situated to view its advantages with its disadvantages. As a place of abode, the country is, without doubt, very pleasant, and far superior to the city during the summer months; but is turned from with disgust by many, when fall and winter storms set in. It is true, muddy roads and gravel walks are not equal to nice stone pavements; but it cannot be expected that we shall have everything just as we like it. The country is not adapted to that class of never-stay-athome-people of an evening, especially during winter nights. Home endearments are very sweet to me, and I think should be to all well-disposed persons who wish to lead a moral life; therefore a winter's sojourn in the country was equally as pleasant as the summer. Among the fair sex I could really distinguish no difference; for they all appeared to flutter as fine regalias as ever I wit- 
nessed in the city, and there was no lack for enjoyment or sociability, while the fresh country air, accompanied with healthy exercise, cleared them from the pale and ghostly appearance so prevalent among our city lassies, and imparted a ruddy hue to their checks without the aid of cosmetics. The advantages of society I consicler are vastly superior; for here acquaintances are readily acquired, while better opportunity is afforded for knowing the true character of all with whom you associate. Every one knows their neighbor, which is a singular contrast to city life. For several years I have lived in a city, and not known my next-door neighbor, or anything appertaining to him, although a brick wall is all that intervenes.

Necessity of much walking also gives great opportunity for acquiring that most healthful exercise; and of walks, both pleasant and recreative, we have an abundance stretching far out into the country, over green hills and dales, through lovely fields and shady groves, with plenty to admire and instruct. Rambles are frequent, and productive of much good cheer, causing the heavy step to grow buoyant and the sad. heart to be braced with pleasure. We had no hydrant, with ever-flowing Croton or gas; but a deep well supplied such pure cold water at all times as to obviate the necessity of that indispensable city luxury, ice. For light, we have the modern lamps, which are far more pleasant to work or read by, although not quite as convenient. 
We had four mails every day, and morning papers from the city were received at an early hour, while the evening papers were on hand as soon as the day's work was completed. Of other reading we had an abundance. I had retained my membership to the Mercantile Library, and I was in the city at least once a week, and found it no inconvenience to change books. Many other reasons could be brought to show wherein country life contrasts favorbly with city privileges. Above all things, the great sociability of the people made the most favorable impression upon me, and through this source I derived much valuable information, and was persuaded by them to turn my attention to the great crop of this section, in which every one, to a greater or less extent, seemed to be engaged. There is but one place in the United States where more onions are raised than in this section, and that is Danvers, Mass., where it has been stated they raise two hundred thousand bushels a year. The New York market is principally supplied from this section, and it would be a low estimate to state the yield of this town to be one hundred and fifty thousand bushels a year. It is no unusual case for farmers about town to raise from four to six hundred bushels per acre, bringing prises from two to eight dollars per barrel of two bushels. One of our most wealthy citizens commenced here twenty-five years ago, on two rods square of ground, and raised as high as eight acres of this product a season. 
Prices ranged higher during the war than ever before or since; yet at fifty cents a bushel onions remain a very profitable crop. In the cultivation of onions, the first and most important item is the seed and its condition. In other seeds we can readily judge from the appearance whether it will yield good; but with onion seed it is perfectly impossible. Seed over a year old is worthless, and much of the one-year-old seed proves poor. After selecting the most solid, large, deep, and bright seed, it can be further tested by putting into water, when the light seed will rise to the top, and the good will sink. The soil best adapted for the purpose should be of a deep, loamy nature, and have been planted with potatoes or corn two previous seasons. When the ground has been cleared of the crop in the fall, then prepare it for onions, by putting on twenty loads of well-rotted manure, fifty bushels to the load; plough it in deep, and let it remain during the winter. Hog manure is the best, but any kind of strong manure will do. If ashes are to be had, put on one to two hundred bushels per acre in addition. Bone dust is applied as a manure in many cases. The ground should be prepared in the spring for the seed, as soon as it is dry, by harrowing with tooth and brush until it is level and mellow; but not too much so, for onions will bottom better if not too mellow. From three to four pounds of seed per acre are required, which is best sown in drills. Two or more rows can be sown at once by use of an onion- 
planter, which is very simply made, at an expense of three or four dollars. The rows should be perfectly straight, and twelve inches apart. To cover them, take a hoe, setting in well, and shove along over the rows. As soon as they come up far enough to be seen plainly commences the hoeing and weeding, which must be continued as long as there are weeds to be seen. Crops can be raised just as well year after year on the same ground, for they require no rotation of crops, but good manuring, as the first year. If the ground is free from weeds when the crop is gathered, so much the better for next year's crop. When most of the onions get ripe, they are pulled and spread on the ground to dry for a day or two, when they are raked into windrows, and when a little damp at night, put in small heaps until there is no moisture left in the tops. When a dry day comes they are again spread out to dry, and, when properly dry, cast into the barn. They can be kept spread from two to three feet deep, if they are well cured, and placed where plenty of fresh air can circulate through them, until very cold weather, when they must be kept from freezing too much. To prepare them for market they are topped and put in barrels, which are sent down by the market-boats and sold, the barrels being returned to the owner. The expense of raising an acre of onions is placed as a fair average, at one hundred and fifteen dollars. A half crop, - say four hundred bushels, - at fifty cents, would bring two hundred dollars. 
This is a low estimate, both of yield and price. The average yield about here is about six hundred bushels per acre, and the price varies from one to two dollars per bushel. With proper attention, and large drafts upon the bank of muck and manure, a few acres of onions will increase the deposits in the bank of exchange by a large percentage. No crop seems to be devoid of its enemies. With onions we have what is called the onion-fly, for want of a better name, which sometimes commits serious depredations. Sprinkling of ashes is resorted to somewhat; but does not have the desired effect of exterminating them. Steeping seeds slightly in salt brine, before sowing, has been strongly recommended as a sure cure for the havoc of the insect supposed to be deposited in the seed. I cannot vouch for its success however. 


\section{CHAPTER XVI.}

\section{RESULTS OF FOURTH AND FIFTH YEARS - AGRICULTURAL BOOKS AND}

PAPERS - ARGUMENTS IN FAVOR OF AGRICULTURE.

Aт the close of the third year, I came to the conclusion that in future I should confine my winter labors entirely to the culture of the verbena. In accordance with this decision, I disposed of my whole stock of flowering plants and bulbs, which by their increase brought more than double what I had paid for them three years previous; besides covering all losses by disease and other causes. I disposed of them by advertising in the agricultural papers, and filled most of the orders by mail, - Congress having made provision for carrying small parcels in that manner. After all expenses were paid, I had just threehundred and forty dollars in hand for my stock, which was at once invested in enlarging my greenhouses by the addition of two more, the same size as the others. The verbenas had been transplanted to open ground in the spring, as ornamental flowers for my yard and borders From these, I gathered a large quantity of cuttings, and entered into the winter's work of the fourth year in propagating. 
By spring I had overcome many misfortunes more than ever before experienced, and succeeded in marketing five thousand baskets of verbenas, netting clear of expenses, three thousand one hundred and twenty-eight dollars.

I had paid up, during the winter, for my house and land; had refitted my house outside and inside, and built on another story with a Mansard roof; had repainted it throughout; had also bought a piece of ground of ten acres, down the road about one quarter of a mile, which was the nearest to my place that I could purchase. My object was to cultivate corn, potatoes, and other products for house use, and for keeping my live stock. In the spring, I planted the four and a half acres adjoining the house with onions. This necessitated the hiring of two men, by the year, to assist me. From this plot I raised seventeen hundred bushels of onions, from which I received a net return of three thousand two hundred and eleven dollars, the prices received varying from two to three dollars per barrel. Without going into details, my net returns this year amounted to four thousand nine hundred and eighty-seven dollars, which you will see was but little short of five thousand dollars, after a four years' trial. The whole amount of my worldly goods at this time, including stock, real estate, and cash, was eight thousand and fifty-seven dollars. The following year my profits were not as large, nor the market as good; but not having the expenses of the previous year, my 
balance stood about the same the fifth year. I say about the same; but, to be accurate, it was just fifteen dollars more, making my income just five thousand and two dollars and fifty cents.

I continue to make a specialty of these two crops, verbenas for winter and onions for summer culture, and find sufficient work to keep me fully occupied and amply remunerated. I spend my evenings at home, reading and improving my mind, while my daily labors bring me beneficial and healthy exercise. When I first entered this business, as an experiment, my weight stood at one hundred and twenty-seven pounds. At present I average one hundred and eighty-two pounds, and am fleshy enough to be an alderman.

Having drawn my story out already much longer than I had intended, I am forced to bring it hastily to a close, and, in looking over what I have written, I can see how feebly my points have been explained.

My story is given for the benefit of all who will read, hoping, however, to throw out a light which will shine to advantage for some who will go and do likewise; and in closing I would reiterate the same statement with which I started out, namely, in a word, that a man with brains, and nothing but his hands, can commence and cultivate a small piece of ground, and, by industry and determination, may, year by year, not only provide an ample home, but, with frugality and perseverance, may accumulate in the 
savings-bank that which will be the nucleus of a small fortune. It does not matter how this is done; some prefer one way, some another; kut this road I have followed, and from my experience can safely recommend it to others, and it is open for more than ever will enter upon it.

All men who have acquired wealth will concur in saying that their hardest work was in accumulating the first clear one thousand dollars. I have endeavored to lead you carefully through the starting-points, knowing that your own experience would be of greater aid in after years than aught I could write or advise you. Of course there are those who look upon the tilling of the soil as a low occupation; and every profession has its enemies as well as its advocates. Such have yet a great veil to be withdrawn from their eyes. I can say it is not degrading, but, on the contrary, one of the most useful, honest, pure, noble, and elevating callings in which man can embark; and in this statement I can bring hundreds of our best and able citizens to substantiate me. After perusing this work, you may say, "Well, if that is true it is an exceptional case," and ask, "If it is true, why do not all farmers become rich?" In reply I ask, Can you show me an industrious and systematic farmer who is not growing rich? There are plenty of dull heads and slovenly men who attempt farming, and fail the same as in every other business; but they are no criterion. Secondly, 
allowing that farmers as a rule only did one half as well, would not their profits even then be an argument and encouragement? He who makes haste makes waste; you may conceive that some day you will fall upon some lucky speculation which will open to you the doors of the mine of wealth much easier and quicker; but, be assured, your chances are just one in a thousand. Take the steadygoing man, who plods on regularly but surely, and yearly puts away a small portion, and he will be sure to win. The great beauty of a farm life is that you are not subjected to a constant outlay to live. A good farmer never buys anything he can raise himself. In other occupations you have not this advantage, and you must be daily laying out small sums for expenses and sustenance of life; while the farmer has just as many luxuries and saves just this amount you spend to get what he enjoys.

It is this practice of constant saving, by a rigid and wellplanned economy, that brings in more money than the deep-laid schemes and conniving plans. If you never save, you will never have the wherewith for future use, make as much money as. you like. My final word of encouragement is to you, young man, or young couples just starting out in life, whatever be your occupation, do not despise a small beginning, if it be honest, and save to the uttermost, and you cannot fail to become rich.

If you think there is another or easier way, you have yet to learn that we live in an age when golden apples 
cannot be had for the picking. If you would make your way and home independent in this world, you must needs work for it. If you follow my experience, and adopt the same course, you will succeed. It is assuredly the most healthy and beneficial; the most easily acquired and the surest road to success, while the calling is decidedly the most honorable. You are the producer, without whom the world cannot exist; we must have food to eat, and clothes to wear, so long as we live. Withdraw the producers from the world, and a sorry figure the people remaining would cut. Ruin and desolation would run wild, and miseries untold would exist.

In sacial science we find all trades dovetail together for the general good of the community, - all necessary for the promotion of its welfare, - yet when necessity demands, there are those which can be dispensed with better than others. But last of all can the producer be spared, for he holds the key to the existence of millions. Tell me, then, such a position is not honorable; that it is not a noble calling. Then, I say, go back to the rudiments of a civilized education, and be taught like a child.

I may remark, by way of advice, and not because of any interest $I$ have in them beyond the promulgation of good and practical information for the benefit of my fellowmen, that every person should become a subscriber to standard agricultural papers, for they are of great value both to practical and amateur cultivators. I do not pro- 
pose to influence any person in the favor of one paper to the prejudice of another, for all are good. My favorites are the "American Agriculturist" and "Moore's Rural New Yorker." I have also quite a large library of agricultural works on all subjects; but those which I most prize I can recommend most strongly. But your own judgment should be exercised in your purchases as to those books best adapted to the particular. branch of agriculture you propose to adopt. As books of general reference, I find "Todd's Young Farmer's Manual" to supply every need. It consists of two volumes, entitled respectively "The Farm and Workshop," and "How to make Farming Pay." For books in detail, a new work, just published by Peter Henderson, entitled "Floriculture," supersedes, in my mind, anything before offered on the subject of flowers. "Gardening for Profit," by the same author, "Small Fruit Culturist," by Fuller, and a series of works by Jacques, are worthy of careful perusal and reference. A book written some years ago by a gentleman, formerly a printer in Philadelphia, and who adopted farming with success, entitled "Ten Acres Enough," is a very good book, and full of encouragement.

I cannot fail to notice two little pamphlets recently published in Boston, - the one called "My Ten-Rod Farm; or, \$2,000 a Year," and another called "Farming by Inches," - which I think are books both of 
pleasure and practical value for any one to read who has any idea of cultivating the soil in any capacity. The first shows what a poor woman can do, while the latter will tend to encourage many a broken-down book-keeper, or failed tradesman, who looks out into the dreary waste to see how he can repair his fallen fortunes and ambition. Gentle reader, I leave you to draw your own conclusions from my little book, and whatever you think of doing, I wish you success, and remember that what man has done can be done again. 


\title{
CHAPTER XVII.
}

\author{
CONCLUSION.
}

IT is evident to every person, who has been thrown upon their own resources in life, that the grand desideratum of life is money. How to get it is the all-absorbing question which so perplexes and provokes all mankind. To get money honestly; first for the immediate wants of ourselves and families, and secondly for our future when the sands of life are nearly run out, claims the devotion of a moral man's first years. To be rich is the summit for which so many scramble without looking well to their foothold, and from which, in an evil hour, in a moment, as in the twinkling of an eye, they are cast down, and all their bright visions of prosperity pass silently away as the morning dew beneath the sun, and they find themselves plunged into the deep abyss of despair and destruction, with blighted hopes and a discouraged ambition as the only fruits of all their labors. With a large capital, keen and shrewd business tact, one will succeed where twenty fail in the large competition of our cities. A man without capital has still less chances of success in any occupa- 
tion he undertakes, and therefore thousands must give their services for wages to those who have capital. There are to-day, by actual statistics, in the city of New York alone, ten thousand young men without employment; while as many more are living upon a meagre salary, which barely provides the food they eat. Their home is probably the attie of some one of those abominable dens called boarding-houses, and thus deprived of all the influences of home or a higher life, what wonder is it that the enchantments of gorgeous billiard-halls and the companionship of the corner beer-shop should lure them away from the paths of virtue into idle habits and dissipation, which is the fallow ground for every kind of wickedness. Is it surprising that the morning papers are daily recording such startling sensations of high-handed crime and wickedness, when the devil has such a school of educated persons to draw from? Who is to blame for all of this? To a great extent the employers, who will not pay their employés wages commensurate with the necessities of life; and not having the means of otherwise obtaining the good influences of a higher circle, they give themselves up to spend what little they do have in vile and profane pleasures, and are thus left to go down to ruin, and are finally forced to get money dishonestly when unable to get it honestly. Many a high and noble-minded individual has thus passed his life away and been laid in the Potter's field, not even mourned for by his late com- 
panions in vice. Just so long as this continues, the rich will become more rich and the poor will become more poor. The great greed for money drowns out all conscientiousness and benevolence in our merchants, and it is useless to look to them for a reform. The young men must rise up and take the reins in their own hands, and cast themselves off from being longer serfs to such a people. No relief will come until our young men become educated to understand that they shall withhold their services for themselves.

In the face of all these facts young men from the country, who have good homes and good opportunities for becoming active, honest, and thriving citizens, are daily seeking to make an exchange to their own injury, and the oppression of the already overcrowded city. Thousands now here, who have passed through the fiery ordeals and struggles of poverty in a city, are ready to flee to the country, to any place that will give them an opportunity for a life of usefulness to themselves; while thousands more, without capital, are revolving in their minds, without coming to any satisfactory conclusion, what they can do to make a start for themselves in the world.

One of the greatest evils with which our large cities are afflicted is the constant acquisition of persons from the country, coming hither under the prevailing idea that easier and more lucrative employment may be found. The largest number of our foreign emigrants also prefer 
to remain here and work, carrying a hod rather than work for themselves. Resident fathers are raising families, and their sons must be furnished employment, even if they have to pay employers for taking them and teaching them in the routine of business; and this latter plan is becoming more and more prevalent every year. In the face of such facts, how can a young man, dependent upon his own labor, manage to succeed? Unless a young man has a friend in the city with whom he can board, and make a salary of one hundred dollars supply his other wants the first year, he cannot even make a beginning. The very least for which one can live in the city is ten dollars a week, and that only of the poorest fare and accommodations. It is more than useless for young men to continue crowding into the city, for they are not bencfited thereby either financially or morally.

The very fact of overcrowding the city reduces wages, and thus puts money in the pockets of the employers. For, the more there is to hire out, the less a man can be engaged for, and every employer will take the man who costs him the least for his services, thereby reducing his expenses, and increasing his profits. If you are out of employment, do not come to the city, for there is no reasonable hope of your succeeding. Thousands in the city of New York are to-day out of work, and suffering for the necessaries of life; they are willing and able to work, but there is no work for them. You may not think so, 
yet it is true, that your orn country home furnishes more ample scope for your abilities than any city. There are hundreds here to compete with you in whatever trade or rocation you may cast your lot, and with experience in all the machinations of trade, with which you have no knowledge. It is only those of the most extreme shrewdness and ability that make any headway at all. The temptations and corruptions of a city life are unbounded. If you are a farmer, continue to labor on, and lay the foundation for your future home in your own country town. It is growing to be an honor to be a farmer, while its remuneration is always sure. Agriculture is now becoming a science. If you have no trade, by all means secure one at once; so that when all else fail, there will be some one thing in which you are skilled, and by which you can make an honest living. If you are already a mechanic or journeyman, in any branch or rocation, you will find it equally true that the country is a better field for your labors. Should you aspire to positions of honor and trust, which are within the gift of the people, work your way up among your friends, where jou are known. It is more easily achieved, and of far greater honor when thus obtained, than when purchased by passing through the fiery ordeal of knavery and trickery, as is so often the case in our large cities.

The field for usefulness lies open before your very eyes. You have not one mile to journey towari it. If you are 
a mechanic or journeyman, you can live where you are inclined. Where your work is, there you may live. You will not find it so in our cities. All our large manufacturers, of whatever class, have their manufictory in some country villacge, griving them more room for less money. Notice and follow their wisclom thus displayed. If you choose to cultivate the soil, get or hire a small place, commence, and be sure and have something to sell at all times. Raise it, make it, or in some way produce yourself, both for your own use, and for others. Do not depend upon others to produce for you. If you are too far from a good market, get near one, and follow their maxims, and I am sure you will succeed.

I have made these statements from a large and extended experience. I have run a complete race of hardships in struggling to keep myself above water, and at last have found my vocation. I have been surprised that I had not arrived at so simple a method before; but it has not equalled that I have, when I see young men so foolishly led away by a blind hope of making a fortune if they could only get into the city. I am satisfied there is much more room than ever will be occupied outside of the eity, and that in the city everything is more than full. If, then, you choose to heed my advice, and take warning, you will find ample scope for your abilities in your own country home; and I feel warranted in saying, that in so doing you will achieve honor and success. 
If you will throw your whole soul into farming, with the determination to succeed by it, you will achieve success. Only treat it just as well as any other business, and you will succeed. The earth is a bank, into which you can make your deposits with a certainty of a larger percentage in return than in any stock or mercantile investment, while there is no fear of defalcation or robbery. There is no fear of a sudden financial crisis to sweep away all your capital. Mother Earth continues to bear and grow vegetation, with which to replenish your treasury through all the financial storms and revulsions just the same, while the agricultural press and inventive genius of the people are daily ennobling and aggrandizing the profession, increasing knowledge, and aiding to lighten the labors attendant upon the cultivation of the soil. The farmer is confident of his living, if nothing more, while his chances for success are far superior; and while he is privileged to rest his weary body in the pure God-given air, so promotive of health, he is still conscious his labors are not fruitless, and that what he has sown is growing while he sleeps. The world is dependent upon the producer for its life. If he fails, the world wanes. People must live, and some one must produce that they may live; and in this noble calling we have been privileged to enter.

A visit to some of our famous markets, such as Washington Market, of New York City, cannot fail to produce a 
correct impression of the great demands of life, and how they are supplied, as well as the grand position of him who grows the supplies. How every variety of living vegetation may be seen, and plainly watched to the place of its consumption, with a rapidity which indicates unmistakably that the demand is clearly beyond the supply.

For a moment consider the statistics of the increase of population in New York city for the last ten years, all of which are consumers, and compare it with the increase of producers, and you will find the former nearly double in ratio that of the latter every year. Increase of inhabitants, both by natural birth and by foreign emigration, all of whom cling fondly to the city and all its enchantments, go to swell the ranks of consumers. These things are inevitable, and must be prepared for, and so long as these facts remain unchanged, there will be no glut in the market, and prices of all products will hold good and amply repay the producer. What is true of New York city is only too true of every other.

THE END. 






$x \operatorname{coc}=2 \cos 5$

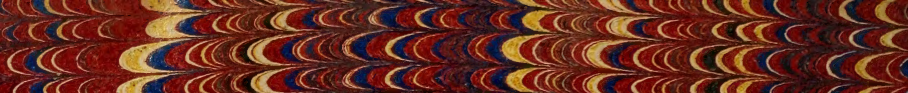

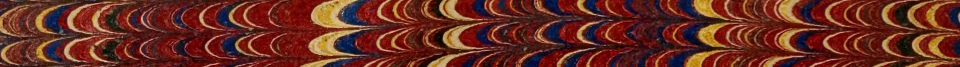

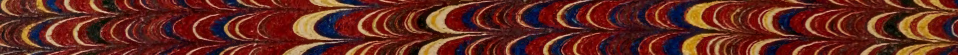

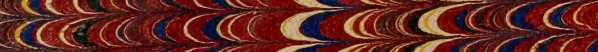

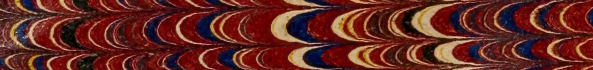

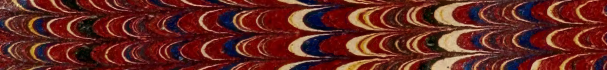

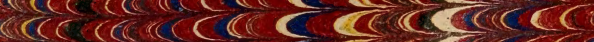

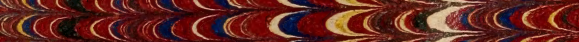

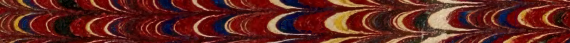

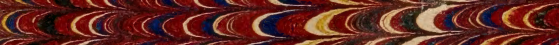

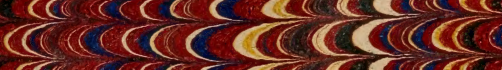
derces receses

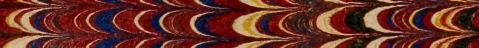

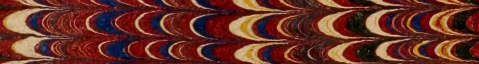

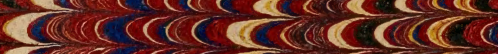

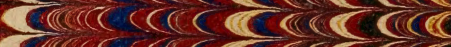

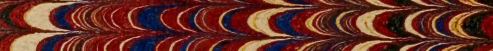

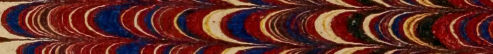

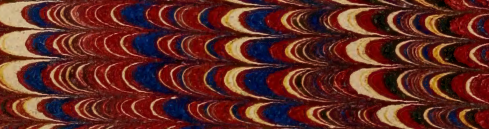

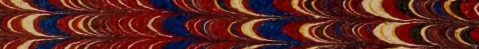

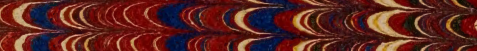

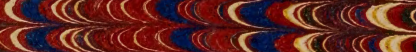

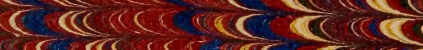

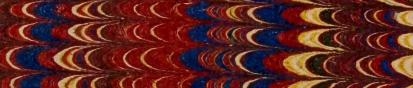

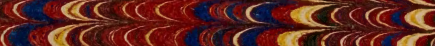

seciner yerex

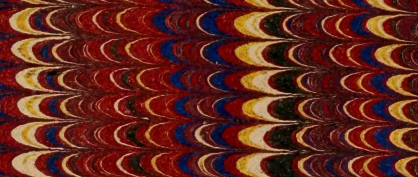

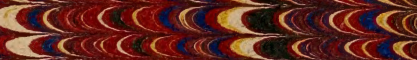

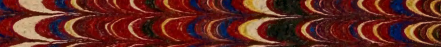

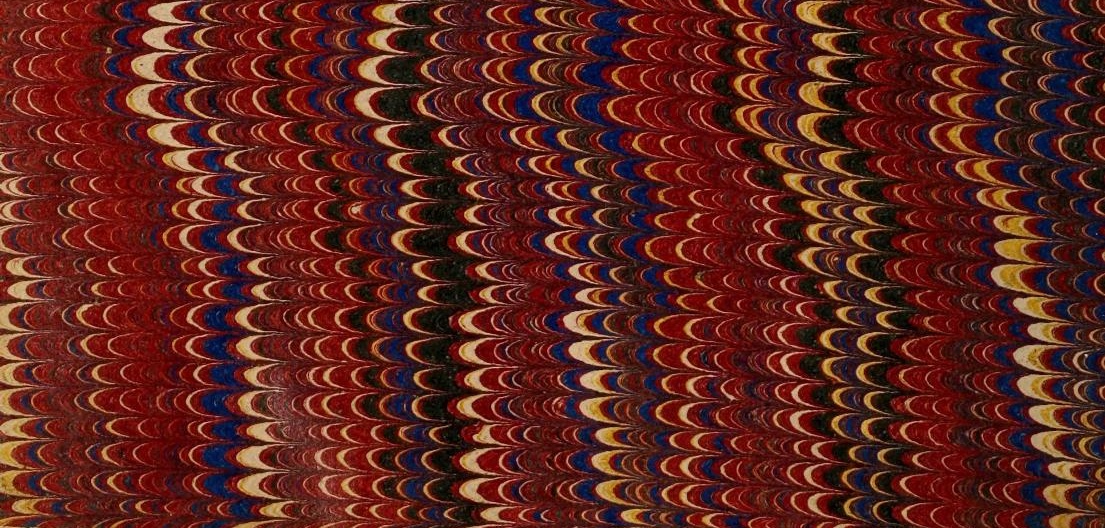

c

(a)

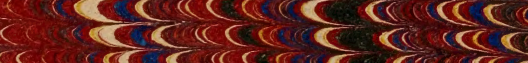

ce

(c)

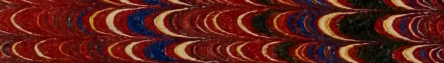

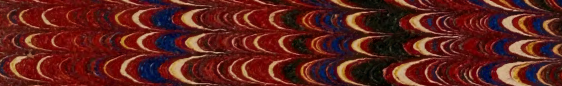
तc सेखिएक

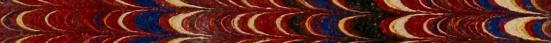

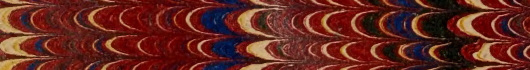

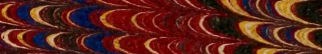

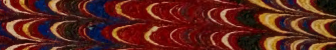
बरालिख खिए बरिए त) तर बि कर लरे

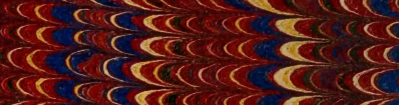
करेखिए लेखिए सराले कितer दिलिखे लिखा तc ब

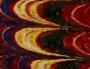
(e) cc $\mathrm{ccc}$ ce

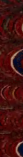<smiles>ClC1(Cl)C2CC3CC(C2)C31</smiles>
$\Leftrightarrow$
तब

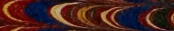

C. तere

C. COC

$C$

cos c
Cive 



\section{LIBRARY OF CONGRESS}

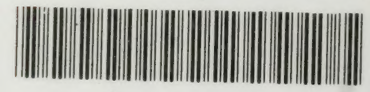

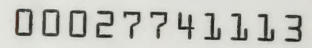

